\title{
Relation Between Ground-Water \\ Quality and Mineralogy in the \\ Coal-Producing Norton Formation of \\ Buchanan County, Virginia
}

By JOHN D. POWELL and JERRY D. LARSON 


\title{
DEPARTMENT OF THE INTERIOR
} DONALD PAUL HODEL, Secretary

\author{
U.S. GEOLOGICAL SURVEY \\ Dallas L. Peck, Director
}

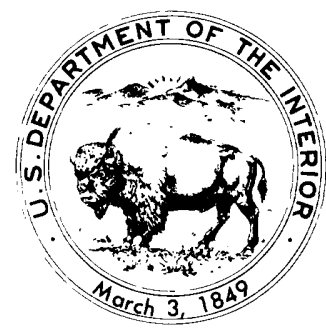

UNITED STATES GOVERNMENT PRINTING OFFICE: 1985

For sale by the Distribution Branch, U.S. Geological Survey, 604 South Pickett Street, Alexandria, VA 22304

Library of Congress Cataloging in Publication Data

Powell, John D.

Relation between ground-water quality and mineralogy in the coal-producing Norton Formation of Buchanan County, Virginia.

(United States Geological Survey water-supply paper; 2274) Bibliography: p. 21

Supt. of Docs. no.: I 19.13:2274

1. Water quality-Virginia-Buchanan County. 2. Water, Underground-Virginia-Buchanan County. 3. Geochemistry - Virginia-Buchanan County. I. Larson, Jerry D. II. Title. III. Title: Norton formation of Buchanan County, Virginia. IV. Series: U.S. Geological Survey water-supply paper ; 2274.

TD225.B87P69 $1985 \quad 553.7^{\prime} 9^{\prime} 09755 \quad 84-600354$ 


\title{
CONTENTS
}

\author{
Abstract 1 \\ Introduction 1 \\ Background 1 \\ Purpose and scope 1 \\ Climate 2 \\ Physiography 2 \\ Geology 2 \\ Hydrology 3 \\ Acknowledgments $\mathbf{6}$ \\ Mineralogy of the Norton Formation 6 \\ Chemical weathering $\mathbf{6}$ \\ Silicate hydrolysis 6 \\ Carbonate dissolution 7 \\ Sulfide oxidation 7 \\ Water chemistry $\mathbf{8}$ \\ Mineral-water relation $\mathbf{8}$ \\ Ridgetop spring 14 \\ Hillside well 15 \\ Valley well 16
}

Evolution of water chemistry in the Norton Formation 17

Comparison of water chemistry within unmined and mined basins 18

Effects of mines on ground-water quality

19

Summary and conclusions

20

Selected references $\mathbf{2 1}$

Metric conversion factors

30

\section{FIGURES}

1. Map showing location of study area in Buchanan County, Va. 2

2. Correlation section showing strata observed in core holes along ridge $\mathbf{3}$

3. Map showing locations of core holes in the Norton Formation along north- to southtrending ridge 4

4. Correlation of coalbeds in Buchanan County, Va., with coalbeds in adjacent states $\mathbf{5}$

5. Map showing locations of springs and wells in study area 9

6-8. Scatter diagrams of:

6. Specific conductivity of water sampled from wells and springs versus altitude $\mathbf{1 0}$

7. Activity of sodium versus activity of calcium $\mathbf{1 0}$

8. Activity of bicarbonate versus activity of sulfate $\mathbf{1 0}$

9-11. Diagrams showing:

9. Relation of ground water sampled in the study area within the stability fields of anorthite, gibbsite, kaolinite, and Ca-montmorillonite at $25^{\circ} \mathrm{C}$ and 1 atmosphere 10

10. Relation of ground water sampled in the study area within the stability fields of albite, gibbsite, kaolinite, and Na-montmorillonite at $25^{\circ} \mathrm{C}$ and 1 atmosphere $\mathbf{1 1}$

11. Relation of ground water sampled in the study area within the stability fields of muscovite, gibbsite, kaolinite, and microcline at $25^{\circ} \mathrm{C}$ and at 1 atmosphere 11 


\section{TABLES}

1. Coal reserves and 1980 production in Virginia 1

2. Chemical analyses of water from the spring and wells used in geochemical reaction models 12

3. Results of speciation calculations using WATEQF 13

4. Selected sets of plausible phases for mass-balance calculations 14

5. Results of reaction model mass-balance calculations for the ridgetop spring $\mathbf{1 4}$

6. Results of reaction model mass-balance calculations for the hillside well $\mathbf{1 5}$

7. Results of reaction model mass-balance calculations for the hillside well using carbon-13 data 16

8. Results of reaction model mass-balance calculations for the valley well $\mathbf{1 7}$

9. Results of reaction model mass-balance calculations for the valley well using carbon13 data 18

10. Analytical data for low flow in Grissom Creek and Barton Fork $\mathbf{1 8}$

11. Results of speciation calculations using WATEQF for low flow in Grissom Creek and Barton Fork 19

12. Results of mass-balance calculations for low flow in Grissom Creek and Barton Fork 20

13. Comparison of mineral weathering in millimoles per kilogram of water in unmined and mined basins based on models 1 and 3 , table $12 \quad 20$

14. X-ray diffraction analyses of rock samples 24

15. Sulfur analyses of rock samples 27

16. Chemical analyses of ground water sampled in the study area 


\section{Relation Between Ground-Water Quality and Mineralogy in the Coal-Producing Norton Formation of Buchanan County, Virginia}

By John D. Powell and Jerry D. Larson

\section{Abstract}

The geochemical processes controlling ground-water chemistry in the coal-producing strata of southwestern Virginia include hydrolysis of silicates, dissolution of carbonates, oxidation of pyrite, cation exchange, and precipitation of secondary minerals, kaolinite and goethite.

Core material from the Norton Formation of the Pennsylvania Period is composed of slightly more than one-half sandstone; siltstone and minor amounts of shale, clay, and coal account for the majority of the remainder. Petrographic analyses and $x$-ray diffraction studies indicate that the sandstone is about 75 percent quartz, 15 percent plagioclase feldspar, 2 percent potassium feldspar, 2 percent muscovite, 4 percent chlorite, and 1 percent siderite. Calcite is present in small amounts and in a few strata as clasts or cement. No limestone strata were identified. The siltstone is about 50 percent quartz, 10 percent plagioclase feldspar, 10 percent mica, 20 percent chlorite, and from 0 to 25 percent siderite. Pyrite is associated with some siltstone and, where present, generally accounts for less than 1 percent. Total sulfur generally constitutes less than 0.1 percent of core samples but about 4 percent in the more pyrite-rich layers

Three reaction models are used to account for the observed water chemistry. The models derive sulfate from pyrite, iron from pyrite and siderite, calcium from plagioclase and calcite, sodium from plagioclase and cation exchange, magnesium from chlorite, and carbon from carbon dioxide, calcite, and siderite. Kaolinite, chalcedony, and goethite are formed authigenically. Carbon-13 data define the relative contributions of carbon sources to models.

Comparison of adjacent unmined and mined basins indicates that surface mining significantly increases the weathering reaction of pyrite in contrast to weathering reactions of other minerals. However, in the area studied, reactive pyrite does not appear to be present in sufficient quantities in strata associated with mined coal seams to cause acid mine drainage.

\section{INTRODUCTION}

\section{Background}

The Appalachian Plateau of southwestern Virginia is a major coal-producing area. According to the Virginia Division of Mineral Resources (VDMR), approximately 4l million short tons were mined in 1980 and 9,900 million short tons remain in place (table 1).
The presence of coal and its associated mineralogy can degrade ground-water quality. Further degradation may occur as a result of mining activities that increase rock surface area and expose fresh strata to the actions of oxygen, water, and bacteria. This deterioration of water quality is referred to as "acid mine drainage" when the potential free acidity exceeds alkalinity and sulfate concentration is greater than 250 milligrams per liter.

It is hypothesized that, as ground water passes through rock strata, chemical reactions with the mineralogy take place; through the reactions the water takes on a unique quality that reflects the combined effects of mineralogy, residence time, and flow system. Of particular importance are reactions that produce and buffer acid.

\section{Purpose and Scope}

The purpose of this report is to propose, through geochemical modeling, those reactions between water and host mineralogy that control ground-water quality in the coalproducing area of southwestern Virginia.

Table 1. Coal reserves and 1980 production in Virginia

[Data in millions of short tons]

\begin{tabular}{lrc}
\hline County & Reserves & Production \\
\hline Buchanan & $3,389.78$ & 17.72 \\
Dickenson & $2,469.27$ & 5.89 \\
Lee & 437.27 & 1.18 \\
Russell & 669.36 & 1.48 \\
Scott & 104.27 & .01 \\
Tazewell & 682.54 & 2.19 \\
Wise & $2,119.24$ & 12.54 \\
\hline \multirow{2}{*}{ Total } & $9,871.73$ & 41.01 \\
\hline
\end{tabular}


The work involved collecting rock core samples to define the mineralogical composition of rocks, collecting ground-water samples from springs and wells to document the changes in water quality as ground water moves from higher altitudes to lower altitudes, and collecting surfacewater samples at low base flow to document differences in water quality between a mined basin and an unmined basin. Data were collected during 1981 as part of the U.S. Geological Survey coal hydrology program.

\section{Climate}

The average annual temperature is $54^{\circ} \mathrm{F}$. The coldest month is January $\left(34.4^{\circ} \mathrm{F}\right.$.) and the warmest month is July $\left(76.6^{\circ} \mathrm{F}\right.$.). Average annual precipitation is approximately 44 inches. The highest monthly averages are in March (4.0 inches) owing to late winter rains and July (4.2 inches) owing to summer thundershowers. The lowest monthly precipitation occurs in October ( 2.0 inches) during the driest part of the year. Snowfall averages 20 to 30 inches per year.

\section{Physiography}

The study area (fig. 1) is located in Buchanan County, $\mathrm{Va}$., and occupies approximately 4 square miles within the
Appalachian Plateau province of southwestern Virginia. The area is characterized by narrow valleys and ridges and steep valley walls. Altitudes range from 1,800 to 2,500 feet above sea level.

\section{Geology}

The coal-producing area of southwestern Virginia lies within the Appalachian Plateau province. Rock strata include, in ascending order, the Lee, Norton, and Wise Formations of the Pennsylvania Period. These formations are composed of nearly flat-lying beds of clastic sedimentary rocks including quartzose sandstone, siltstone, shale, clay, and coal. Sandstones, being the more resistant of the strata, form large outcrops along streams and highways and are coated with a brown iron stain. A mantle of weathered material, including thin sandy loam soil, covers the vertically fractured bedrock. Topography is characterized by narrow valleys and steep ridges.

Strata observed in five corings along a ridge within the Norton Formation near Council, Buchanan County, Va. (fig. 2), are representative of the coal-bearing rocks. The area is shown on the part of the $71 / 2$-minute Big A Mountain Quadrangle geologic map in figure 3. The stratigraphic relations of the coalbeds within the ridge with coalbeds in

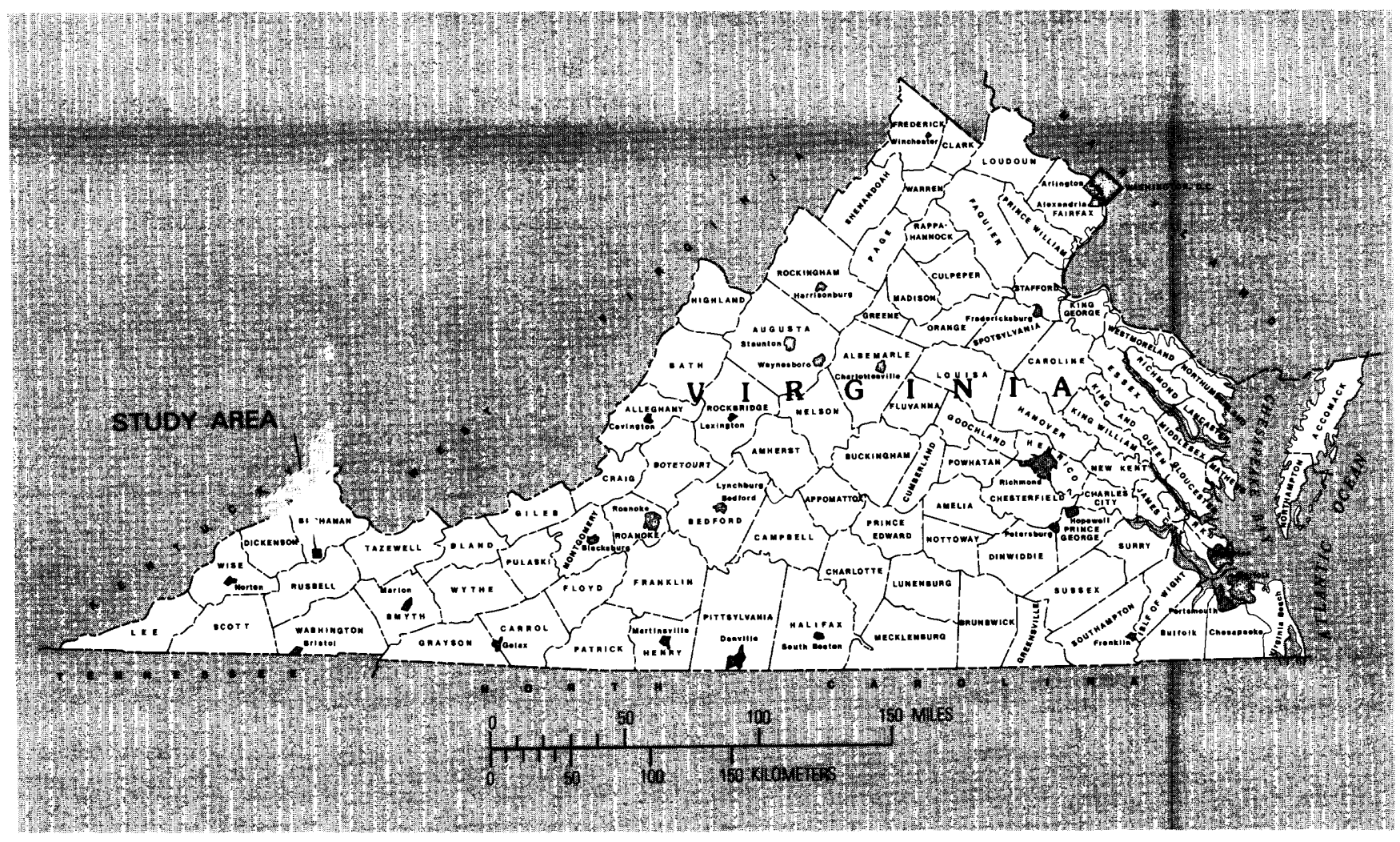

Figure 1. Location of study area in Buchanan County, Va.

2 Relation Between Ground-Water Quality and Mineralogy, Norton Formation, Va. 


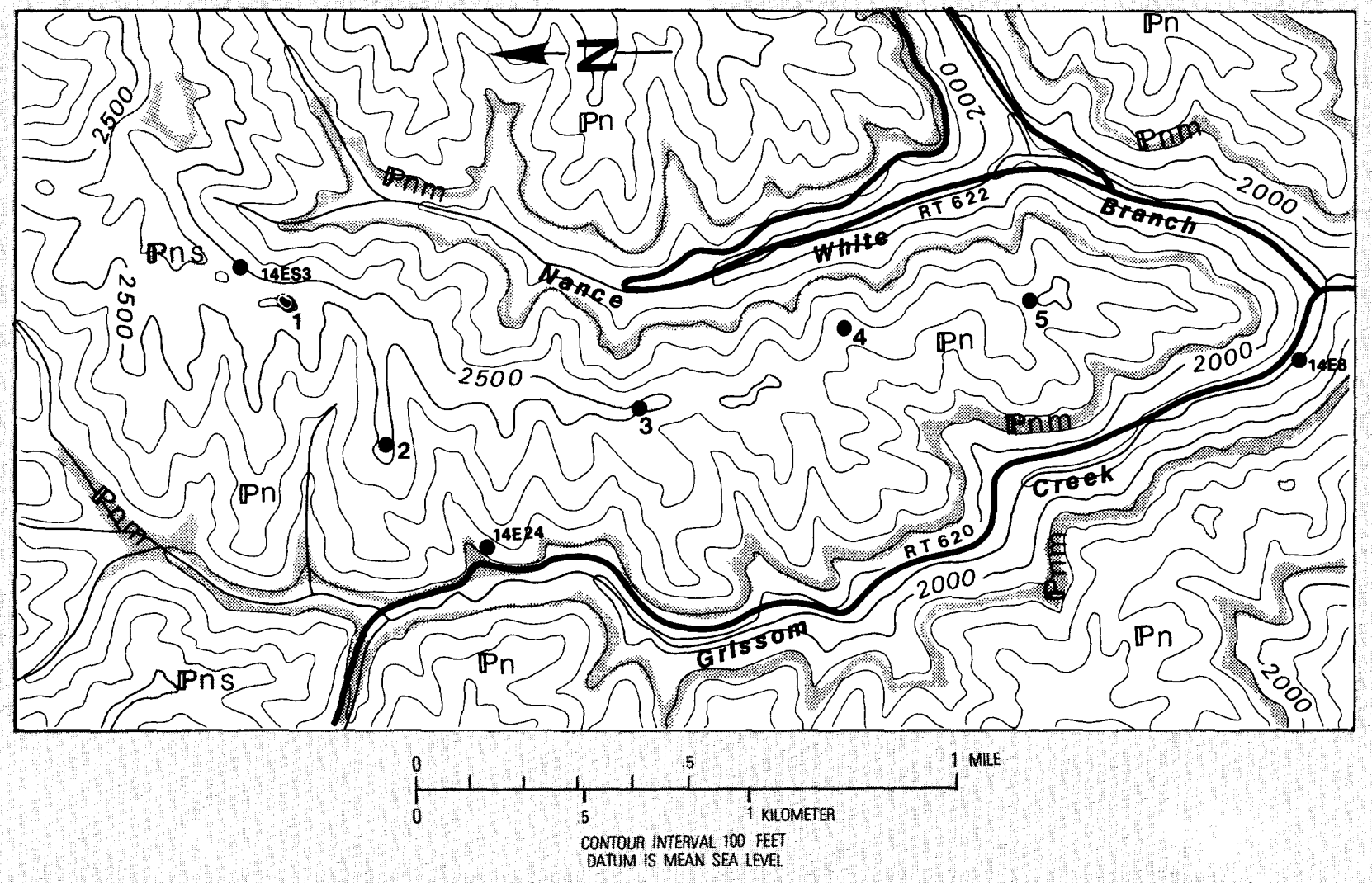

EXPLANATION

IPrm

Pnm Mcclure Sandstone Member

\section{$\mathrm{Pn}$}

Pn sandstone, siltstone, shale and coal

\section{Pns}

Pns Unnamed resistant, prominent sandstone units

- 3 Core hole and identification number

Figure 3. Locations of core holes in the Norton Formation along north- to south-trending ridge. 


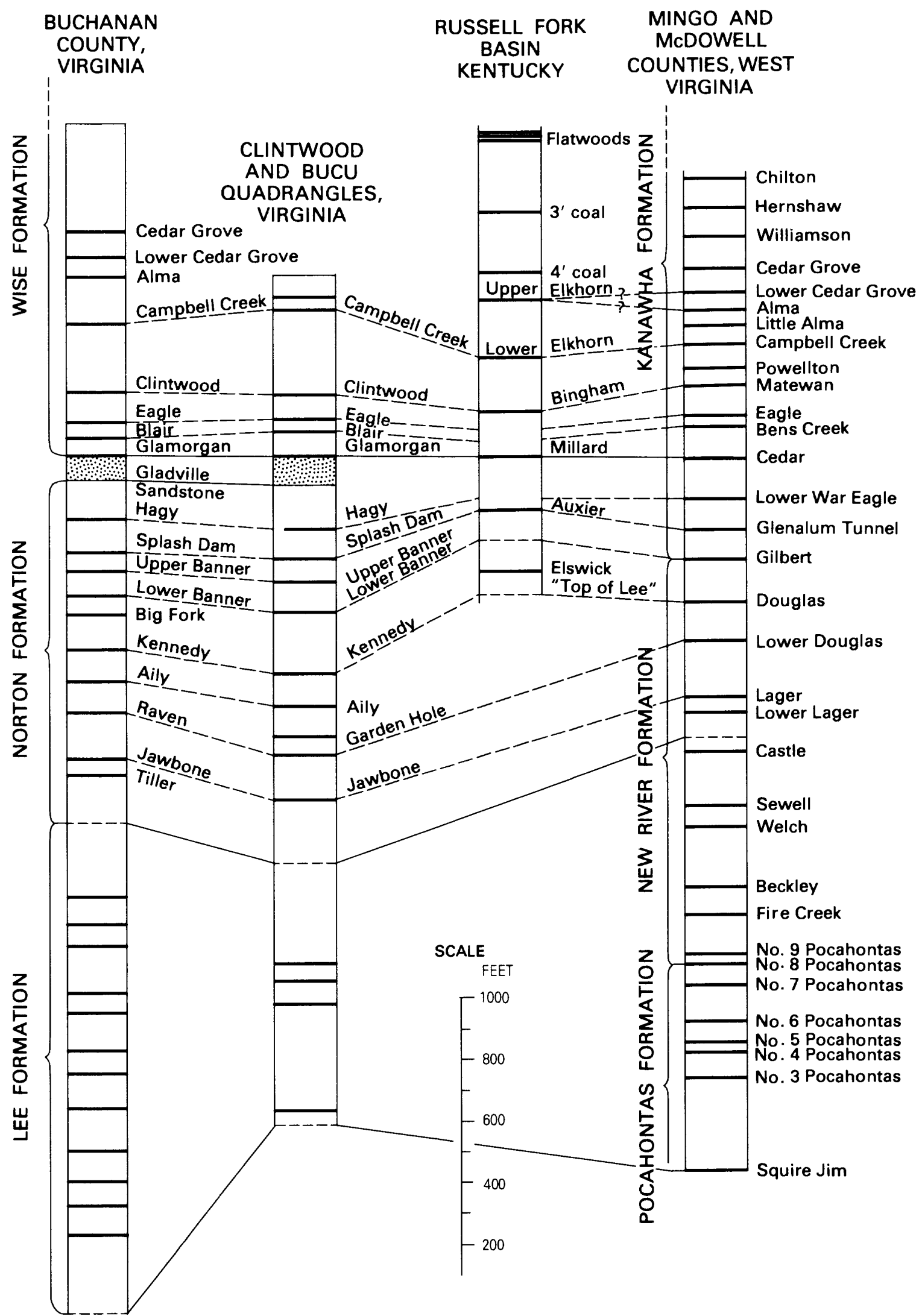

Figure 4. Correlation of coalbeds in Buchanan County, Va., with coalbeds in adjacent states (modified from Hinds, 1918). 
do deeper drilled wells. In the other system, water flows through rock fractures and provides the main source of domestic supply. The strata host a system of perched water tables connected along bedding planes and fractures. Perennial springs issue from sandstones and coals at different altitudes throughout the stratigraphic section.

\section{Acknowledgments}

The authors wish to express their appreciation to the United Coal Company and to residents of the study area for allowing access to core samples and private property. Ollie Fordham and Richard Good of the Virginia Division of Mineral Resources analyzed rock samples.

\section{MINERALOGY OF THE NORTON FORMATION}

A continuous core penetrating 960 feet into the Norton Formation was sampled to determined stratigraphy and mineralogy of the study area. A thorough knowledge of the mineralogy is necessary to identify plausible phases to be included in geochemical reaction models. Samples were taken every 10 feet and at each change in lithology. A total of 129 samples were analyzed. Subsamples of each sample were analyzed by $\mathrm{x}$-ray diffraction to identify the most prevalent minerals, by $\mathrm{x}$-ray fluorescence to determine composition by percent metal oxide, by induction furnace to determine percentage of sulfur present, and by thin-section and petrographic microscope to identify cements. Results of x-ray diffraction analyses and sulfur analyses are provided in tables 14 and 15 (at the end of this report).

The predominant minerals, in order of abundance, are quartz, plagioclase, chlorite, muscovite, siderite, and microcline. Calcite is present as a cement and as clasts in some of the sandstone. No limestone strata were present and no gypsum was identified.

Estimates of composition based on $\mathrm{x}$-ray diffraction data and examination of thin sections indicate that the sandstone is about 75 percent quartz, 15 percent plagioclase feldspar, 2 percent potassium feldspar, 2 percent muscovite, 4 percent chlorite, and 1 percent siderite. The siltstone is about 50 percent quartz, 10 percent plagioclase feldspar, 10 percent mica, 20 percent chlorite, and from 0 to 25 percent siderite. Pyrite is associated with some siltstone and coal and, where present, generally is estimated to be less than 1 percent. Total sulfur generally is less than 0.1 percent, but is about 4 percent in the more pyrite-rich layers.

The Norton Formation in Buchanan County was formed from deltaic, and lagoonal, nonmarine sediments (Virginia Division of Mineral Resources, oral commun., 1983). The amount of pyrite in these strata is, therefore, limited. Pyrite is found, however, in the black siltstones associated with some coal seams and in the coal seams themselves.
Pyritic sulfur in coal is associated with marine sediments of a paralic environment. In these sediments iron is available from oxides, clays, and organics transported from the continent. Sulfur is available from sulfate in marine water. In the paralic environment, water circulation is minimal, thus depleting oxygen within the upper layers of sediment. Sulfate from seawater is reduced in the resulting anaerobic environment and combines, through the action of bacteria, with the iron, which is reduced and mobilized from continental sediments to form pyrite.

Fluvial, deltaic deposits are not conducive to the production of pyrite. The kinetic energy in the fresh surfacewater environment maintains high dissolved-oxygen levels which preclude the reduction of sulfate and ferric iron necessary for the production of pyrite. Some lagoonal areas, however, serve as habitats for pyrite-producing bacteria between floods.

\section{CHEMICAL WEATHERING}

Decomposition of rock materials involves a set of geochemical processes known collectively as chemical weathering. Chemical weathering results from the interaction of ground water that contains oxygen and carbon dioxide and specific minerals. The higher the concentration of gases in the water, the more "aggressive" the ground water becomes. Rainwater has a median $\mathrm{pH}$ of 5.6 owing to carbonic acid produced as rain that passes through the atmosphere and dissolves carbon dioxide (Paces, 1973), as follows:

$$
\underset{\substack{\text { Carbon } \\
\text { dioxide }}}{\mathrm{CO}_{2}}+\underset{\text { Water }}{\mathrm{H}_{2} \mathrm{O}} \Rightarrow \underset{\begin{array}{l}
\text { Carbonic } \\
\text { acid }
\end{array}}{\mathrm{H}_{2} \mathrm{CO}_{3}} \Rightarrow \underset{\text { Hydrogen }}{\mathrm{H}^{+}}+\underset{\text { ion }}{\mathrm{HCO}_{3}^{-}} \underbrace{\text { ion }}_{\text {Bicarbonate }}
$$

The amount of carbonic acid increases further as water passes through soil, in which carbon dioxide can, as a result of plant respiration and aerobic decomposition of organic detritus, be 300 times that of the atmosphere. When ground water containing high concentrations of carbon dioxide contacts rock, decomposition of some minerals begins. Possible reactions of minerals found in the study area with carbonic acid are described below. These chemical reactions generally tend to lower acidity and raise the $\mathrm{pH}$ of ground water.

\section{Silicate Hydrolysis}

The weathering action of ground water on silicate minerals involves hydrolysis. This process consumes $\mathrm{H}^{+}$ and produces clays, dissolved silica, metal ions $\mathrm{CCa}^{2+}$, $\mathrm{Mg}^{2+}, \mathrm{Na}^{+}, \mathrm{K}^{+}$), and bicarbonate ions. A weathering reaction of plagioclase feldspar $\left(\mathrm{Ab}_{0.70}\right)$ follows: 


$$
\begin{aligned}
& \mathrm{Na}_{0.70} \mathrm{Ca}_{0.30} \mathrm{Al}_{1.30} \mathrm{Si}_{2.70} \mathrm{O}_{8}+1.30 \mathrm{CO}_{2}+1.95 \mathrm{H}_{2} \mathrm{O} \\
& \text { Oligoclase } \\
& \underset{\text { Kaolinite }}{\Rightarrow 0.65 \mathrm{Al}_{2} \mathrm{Si}_{2} \mathrm{O}_{5}(\mathrm{OH})_{4}}+0.70 \mathrm{Na}^{+}+0.30 \mathrm{Ca}^{2+}
\end{aligned}
$$

$$
+1.40 \mathrm{SiO}_{2}+1.30 \mathrm{HCO}_{3}{ }^{-} \text {. }
$$

This process produces calcium and sodium ions, dissolved silica, kaolinite, and bicarbonate ions. The reaction consumes hydrogen ions of carbonic acid and produces bicarbonate ions, which increase the alkalinity and $\mathrm{pH}$ of the ground water. Hydrolysis of silicates alone can increase ground-water $\mathrm{pH}$ to 10.0 (Freeze and Cherry, 1979, p. 279). Chlorite is another silicate mineral that makes a significant contribution to the ground-water quality of Buchanan County. A weathering reaction of chlorite is shown below. In this reaction, $\mathrm{Mg}^{2+}$ is released, leaving a talc residue.

$$
\begin{aligned}
& \mathrm{Mg}_{3}(\mathrm{OH})_{6}\left(\mathrm{Mg}_{2} \mathrm{Al}\right)\left(\mathrm{AlSi}_{3}\right) \mathrm{O}_{10}(\mathrm{OH})_{2}+6 \mathrm{H}^{+} \mathrm{HCO}_{3}{ }^{-} \\
& \Rightarrow 3 \mathrm{Mg}^{2+}+\underset{\text { Chlorite }}{6 \mathrm{H}_{2} \mathrm{O}}+6 \mathrm{HCO}_{3}{ }^{-}+\left(\mathrm{Mg}_{2} \mathrm{Al}\right)\left(\mathrm{AlSi}_{3}\right) 0_{10}(\mathrm{OH})_{2} \\
& \text { Talc }
\end{aligned}
$$

The talc layer itself may break down further by reacting with additional hydrogen ions. If so, an even larger amount of $\mathrm{Mg}^{2+}$ may be added to the ground water. Ferrous iron, however, can substitute for magnesium in the chlorite structure and, if released, will oxidize to ferric iron, which in turn will hydrolize to produce $\mathrm{H}^{+}$and to lower $\mathrm{pH}$.

$$
\begin{aligned}
& \mathrm{Fe}^{2+}+2.5 \mathrm{H}_{2} \mathrm{O}+\mathrm{H}^{+} \Rightarrow \mathrm{Fe}^{+3}+0.5 \mathrm{H}_{2} \mathrm{O} \\
& \mathrm{Fe}^{3+}+3 \mathrm{H}_{2} \mathrm{O} \Rightarrow \mathrm{Fe}(\mathrm{OH})_{3}+3 \mathrm{H}^{+}
\end{aligned}
$$

The greater the amount of magnesium present relative to iron, the greater the tendency for chlorite weathering to increase alkalinity and $\mathrm{pH}$.

\section{Carbonate Dissolution}

Carbonate minerals are present as rock fragments and cementing agents in sandstones of the study area. The dissolution of carbonate minerals releases metal ions $\left(\mathrm{Ca}^{2+}\right.$, $\left.\mathrm{Mg}^{2+}, \mathrm{Fe}^{2+}\right)$, and bicarbonate ion and raises the $\mathrm{pH}$ of ground water. Three carbonates, calcite, dolomite, and siderite, are present in the rocks of the study area. Dissolution of these carbonates in the presence of carbonic acid, is shown by the following reactions:

$$
\underset{\text { Calcite }}{\mathrm{CaCO}_{3}+\mathrm{H}_{2} \mathrm{O}+\mathrm{CO}_{2} \Rightarrow \mathrm{Ca}^{2+}+2 \mathrm{HCO}_{3}^{-}}
$$

and

$$
\mathrm{CaMg}\left(\mathrm{CO}_{3}\right)_{2}+2 \mathrm{H}_{2} \mathrm{O}+2 \mathrm{CO}_{2} \Rightarrow \mathrm{Ca}^{2+}+\mathrm{Mg}^{2+}+4 \mathrm{HCO}_{3}{ }^{-} \text {. }
$$

Dokomite

ln these reactions additional bicarbonate ion is produced from the mineral itself, and this ion adds to the bicarbonate remaining from the disassociation of carbonic acid. These reactions can rapidly increase alkalinity and $\mathrm{pH}$.

Carbonate dissolution in the presence of acid produced by pyrite weathering contributes less to alkalinity than does weathering in the presence of carbonic acid.

$$
\underset{\text { Calcite }}{\mathrm{CaCO}_{3}+\mathrm{H}^{+}+0.5 \mathrm{SO}_{4}{ }^{2-} \Rightarrow \mathrm{Ca}^{2+}+0.5 \mathrm{SO}_{4}{ }^{2-}+\mathrm{HCO}_{3}{ }^{-}}
$$

The dissolution of carbonates in the presence of acid produced during pyrite oxidation contributes half as much bicarbonate ion per calcium ion to the alkalinity of the water as does weathering by carbonic acid. Because of this, alkalinity is lower than expected from dissolution of calcite by carbonic acid.

Siderite $\left(\mathrm{FeCO}_{3}\right)$ is by far the most abundant carbonate in the core samples. Of particular importance is the fact that, during weathering, siderite releases ferrous iron, as follows:

$$
\underset{\text { Siderite }}{\mathrm{FeCO}}+\mathrm{H}_{2} \mathrm{CO}_{3} \Rightarrow \mathrm{Fe}^{2+}+2 \mathrm{HCO}_{3}{ }^{-} .
$$

Ferrous iron released subsequently oxidizes (reaction 4) and hydrolizes (reaction 5), releasing $\mathrm{H}^{+}$. The $\mathrm{H}^{+}$produced will be neutralized by the $\mathrm{HCO}_{3}{ }^{-}$derived from the carbonic acid and siderite. The net effect is that siderite dissolution in the presence of carbonic acid supplies iron to the ground water but does not produce the acidity that the oxidation of pyrite produces.

\section{Sulfide Oxidation}

The exposure of iron sulfides (pyrite and marcasite) in the rocks to water and oxygen oxidizes the sulfur and iron, which produces sulfate, ferrous, ferric, and hydrogen ions as well as iron hydroxide precipitate, as follows:

Dissolution of pyrite:

$$
\begin{aligned}
& \mathrm{FeS}_{2}+3.5 \mathrm{O}_{2}+\mathrm{H}_{2} \mathrm{O} \Rightarrow \mathrm{Fe}^{2+}+2.0 \mathrm{SO}_{4}{ }^{2-}+2.0 \mathrm{H}^{+} \\
& \text {Pyrite }
\end{aligned}
$$

Oxidation of ferrous iron to ferric iron:

$$
\mathrm{Fe}^{2+}+.25 \mathrm{O}_{2}+\mathrm{H}^{+} \Rightarrow \mathrm{Fe}^{3+}+0.50 \mathrm{H}_{2} \mathrm{O}
$$

Hydration of ferric iron:

$$
\mathrm{Fe}^{3+}+3 \mathrm{H}_{2} \mathrm{O} \Rightarrow \mathrm{Fe}(\mathrm{OH})_{3(\mathrm{~s})}+3 \mathrm{H}^{+}
$$


Total reaction:

$$
\begin{aligned}
& \mathrm{FeS}_{2}+3.75 \mathrm{O}_{2}+3.50 \mathrm{H}_{2} \mathrm{O} \Rightarrow \\
& \mathrm{Fe}(\mathrm{OH})_{3(\mathrm{~s})}+2.00 \mathrm{SO}_{4}{ }^{2-}+4.00 \mathrm{H}^{+}
\end{aligned}
$$

In this series of reactions, 4 moles of hydrogen ion are produced from the oxidation of 1 mole of pyrite. Because there is no mineral source of sulfate, the concentration of sulfate in the ground water under oxidizing conditions indicates the amount of pyrite oxidation taking place within the ground-water system.

In the event of oxygen depletion, as can occur in a closed system, the oxidation of sulfide continues by ferric iron already present in the water (Singer and Stumm, 1968), as follows:

$$
\mathrm{FeS}_{2}+14 \mathrm{Fe}^{3+}+8 \mathrm{H}_{2} \mathrm{O} \Rightarrow 15 \mathrm{Fe}^{2+}+2 \mathrm{SO}_{4}{ }^{2-}+16 \mathrm{H}^{+} .
$$

This process contributes additional $\mathrm{H}^{+}$and ferrous iron to the water. This ferrous iron is then a potential source of large amounts of $\mathrm{H}^{+}$in this chemical environment should oxygen again enter the system.

\section{WATER CHEMISTRY}

Samples of well water were collected from the wellhead where possible and from pressure tanks. In all cases, the pumps were allowed to run as long as possible before collecting a sample of ground water. Spring samples were collected as close as possible to the fracture or bedding plane from which they issued.

Temperature, $\mathrm{pH}$, conductivity, and alkalinity were determined in the field at the time of collection. Filtering was accomplished using 0.45 -micrometer membrane filters. In order to have as accurate as possible a value for dissolved iron for speciation calculations, samples whose analyses were used in geochemical modeling were filtered using 0.1 -micrometer membrane filters. Analyses were provided by the U.S. Geological Survey central laboratory in Atlanta, Ga. Carbon-13 and dissolved gas samples were collected and analyzed according to the method described by Thorstenson and others (1979). Dissolved species activities and mineral phase saturation indexes were calculated using the U.S. Geological Survey computer program WATEQF ${ }^{1}$ (Plummer and others, 1978).

Twenty wells and twelve springs were sampled throughout the strata. Locations of the wells and springs sampled are shown in figure 5. Analyses of ground-water samples are provided in table 16 (at the end of this report).

The hypothesis that water quality changes from the recharge area at the top of the ridge to the discharge area at the base of the ridge is supported by figure 6. Specific

${ }^{1}$ WATEQF is an acronym for WATer EQuilibrium. Fortran. conductance of ground water generally increases from the top of the ridge toward the base of the ridge.

In the scatter diagrams presented in figures 7 and 8 , springs, dug wells, and drilled wells in the Grissom Creek basin appear as separate groups. Water from springs is characterized by lower activities of sodium, calcium, and bicarbonate than water from dug wells or drilled wells. Water from dug wells is characterized by higher activity of sulfate than water from drilled wells. Water from drilled wells is characterized by higher activities of bicarbonate and sodium than water from springs or dug wells.

The separation of points in figures 7 and 8 into groups suggests that water quality in springs, dug wells, and drilled wells may have separate histories of formation. Springwater tends to have lower constituent activities because of shorter residence time in the rock. One spring (14ES5), found near a valley bottom, contains water similar in composition to springs near the ridgetop. This spring apparently contains water that moves quickly through fractures to the lower altitude.

Water from drilled wells is characterized by greater dissolved solids than is water from springs or dug wells, indicating a longer residence time. Greater activities of sodium resulting from ion exchange in water from drilled wells also indicate a longer residence time.

Water from dug wells exhibits lower activities of sodium and bicarbonate ions than does water from drilled wells. This water apparently flows through the weathered soil zone overlying bedrock and has a shorter residence time than water found in drilled wells.

All water samples fall within the kaolinite stability field when plotted on activity diagrams (figs. 9-11). Kaolinite, then, is considered the stable phase formed during hydrolysis of feldspars.

\section{MINERAL-WATER RELATION}

A geochemical reaction model is an attempt to state what reactions between mineralogy and water have occurred and the extent to which these reactions have proceeded. In this report, each model developed is a listing of solid phases and numerical values for the amount of each phase breaking down chemically or precipitating within the system being modeled.

Mass-balance calculations, when combined with speciation calculations, are a useful tool for defining the possible reactions affecting water chemistry (Plummer and others, 1983). Mass balance is a technique that accounts for masses of reactants and products in a chemical reaction.

$$
\underset{\text { composition }}{\text { Initial water }}+\underset{\text { phases }}{\text { Reactant }} \rightarrow \underset{\text { composition }}{\text { Final water }}+\begin{gathered}
\text { Product } \\
\text { phases }
\end{gathered}
$$

Many combinations of reactant and product phases, if combined with the observed water chemistry, may appear plausible. The number of these combinations, however, can be 


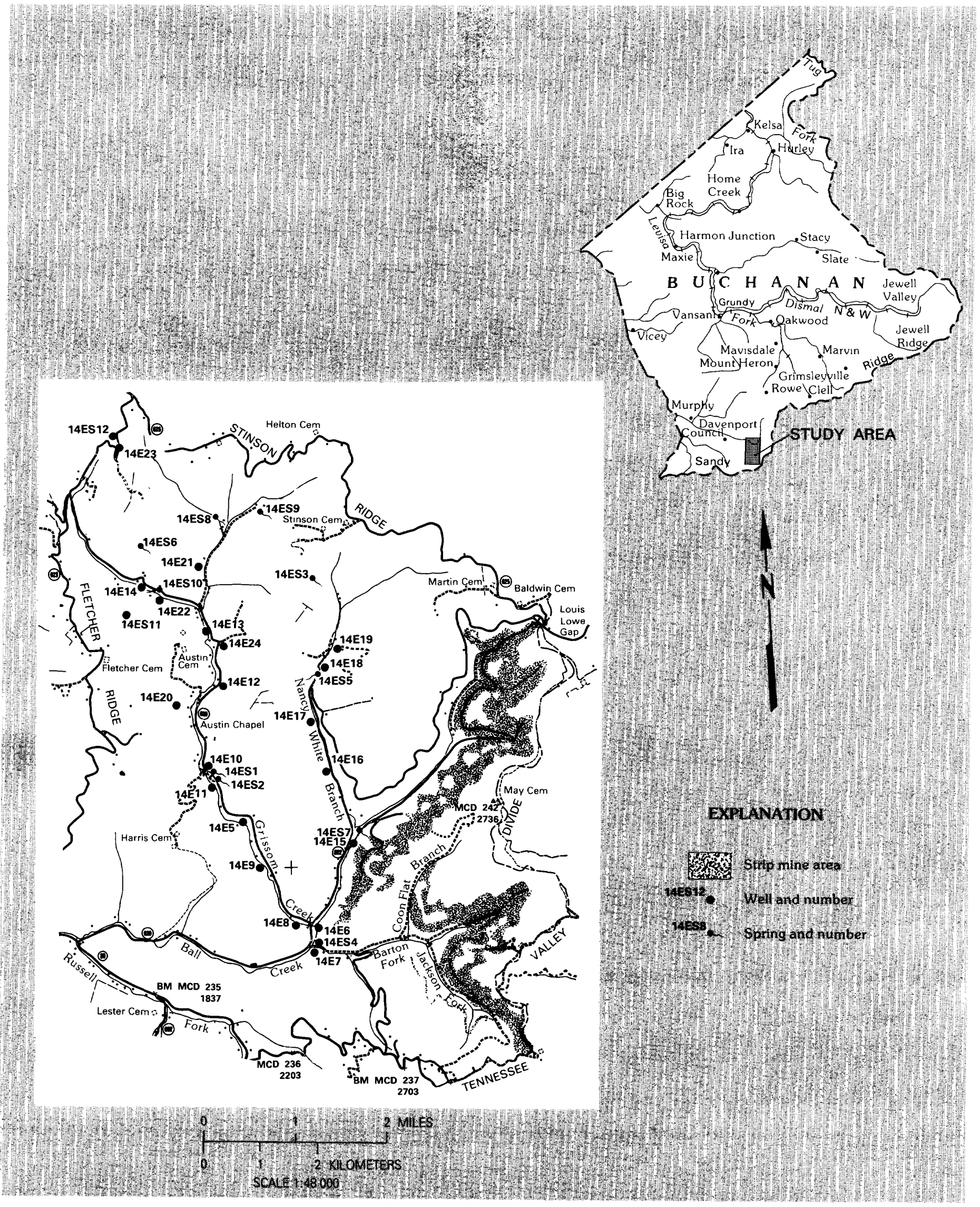

Figure 5. Locations of springs and wells in study area. 


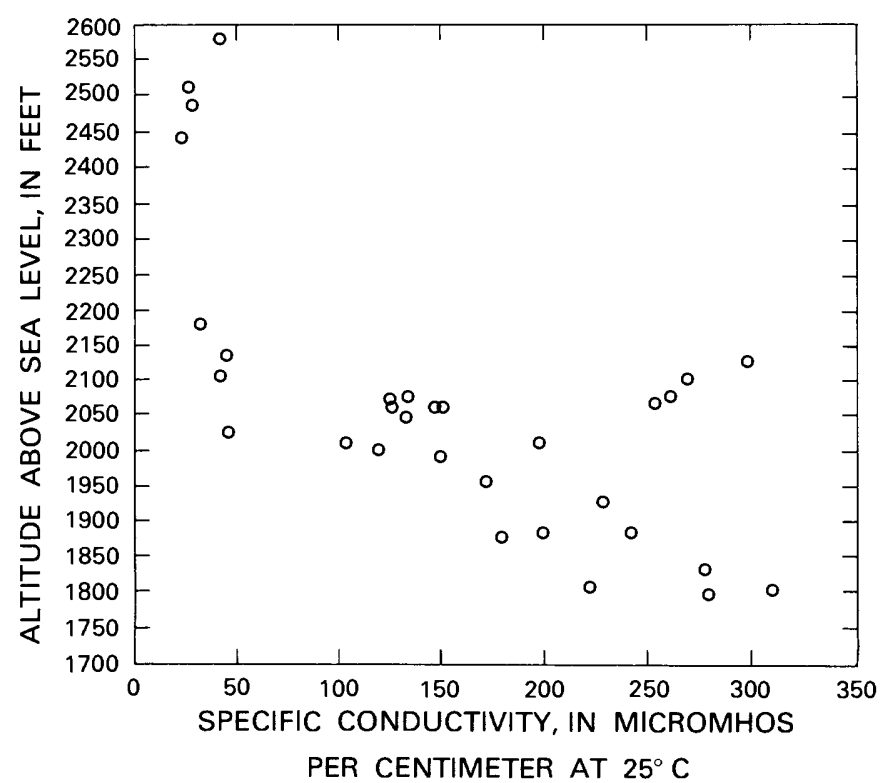

Figure 6. Specific conductivity of water sampled from wells and springs versus altitude.

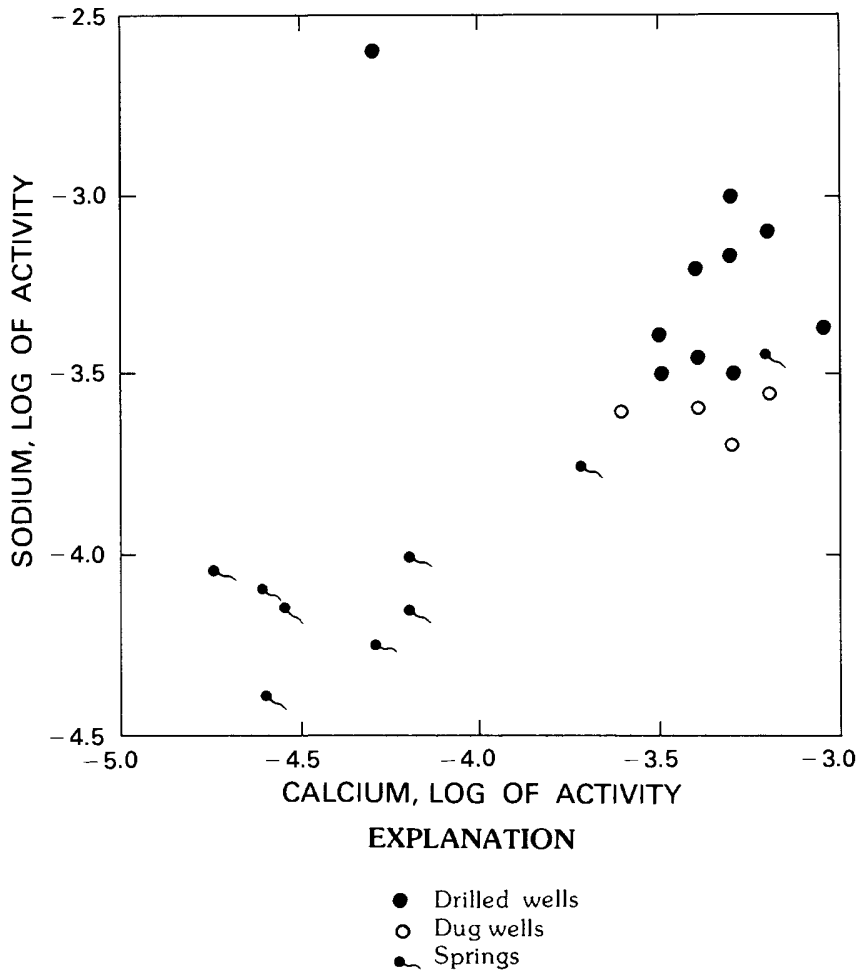

Figure 7. Activity of sodium versus activity of calcium.

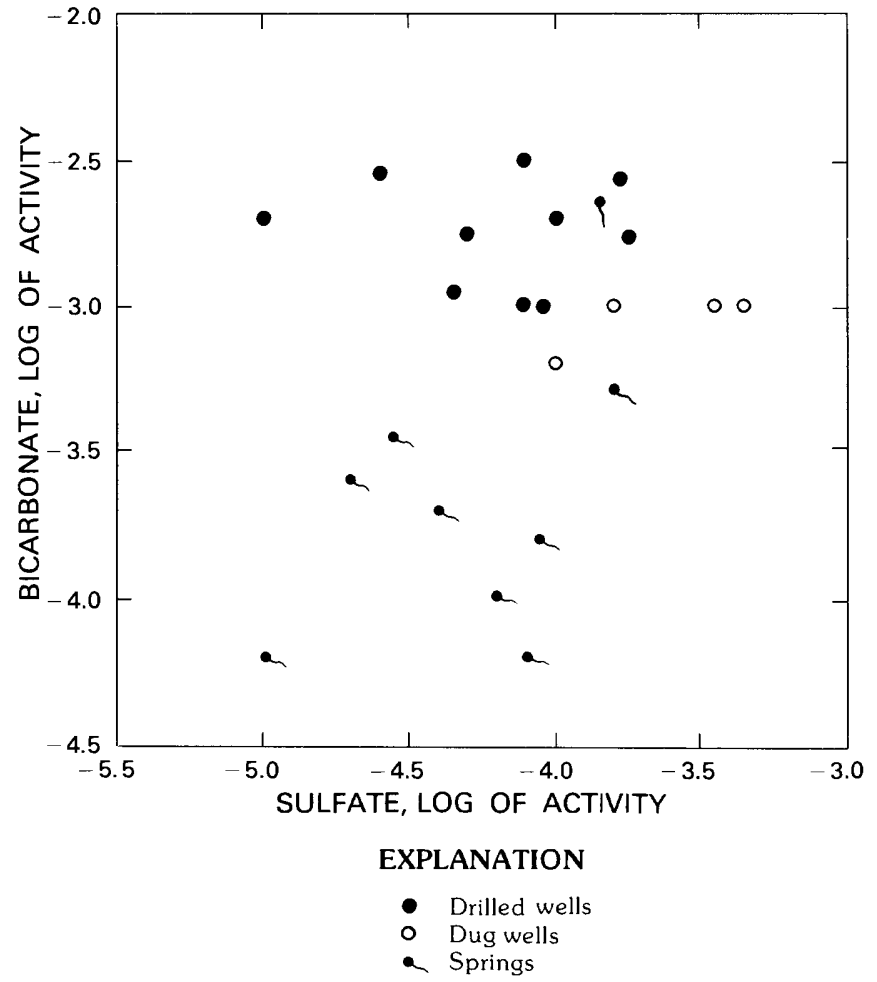

Figure 8. Activity of bicarbonate versus activity of sulfate.

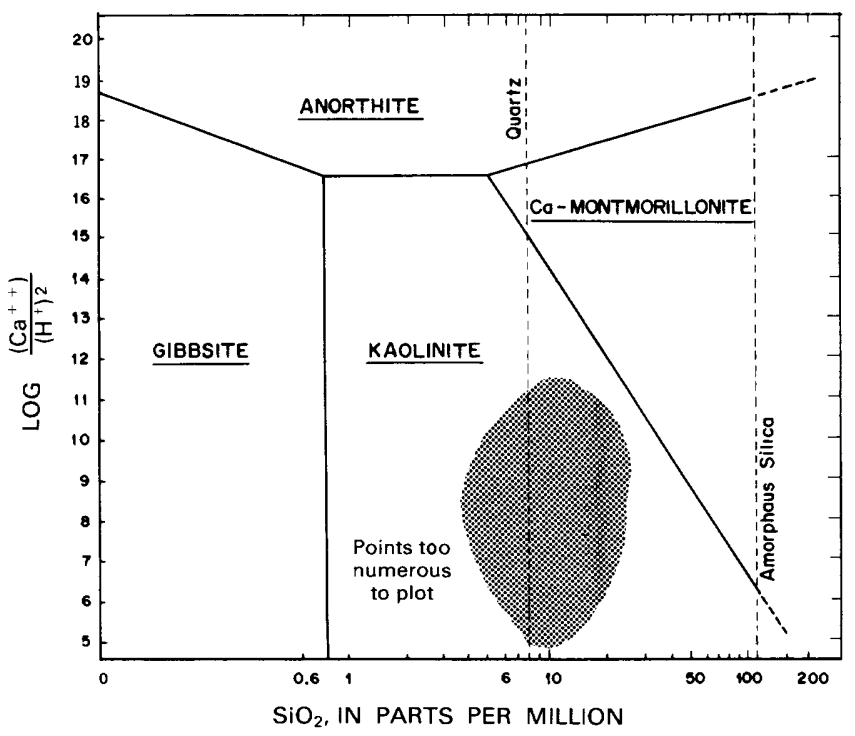

Figure 9. Relation of ground water sampled in the study area within the stability fields of anorthite, gibbsite, kaolinite, and $\mathrm{Ca}$-montmorillonite at $25^{\circ} \mathrm{C}$ and 1 atmosphere (modified from Tardy, 1971). 


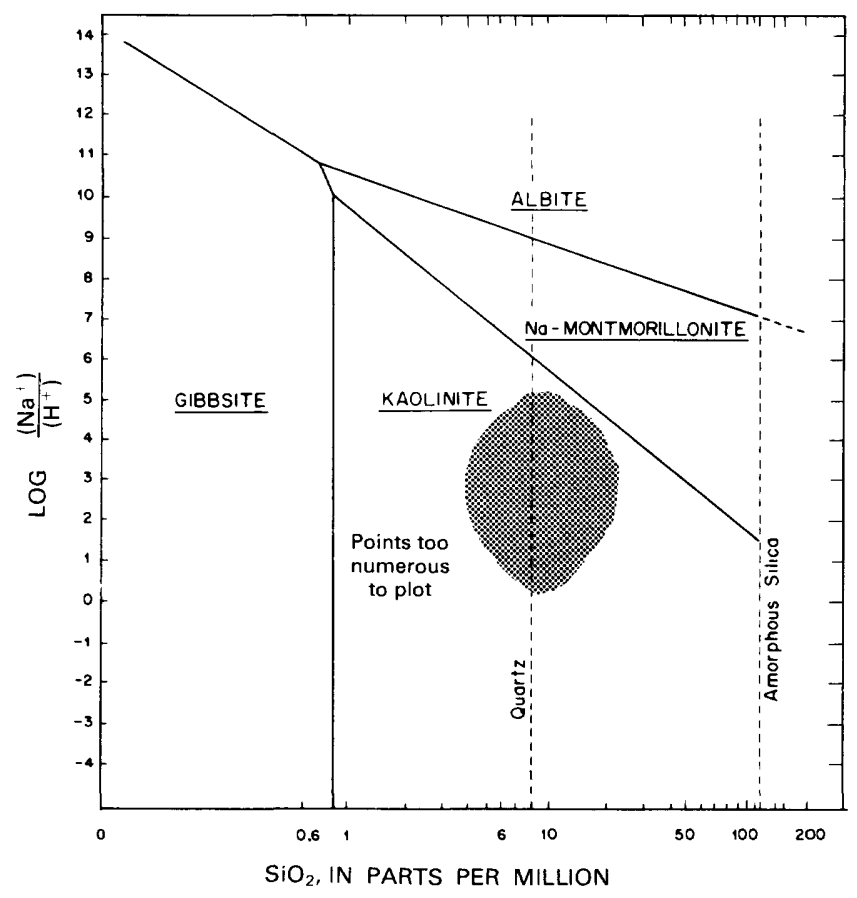

Figure 10. Relation of ground water sampled in the study area within the stability fields of albite, gibbsite, kaolinite, and $\mathrm{Na}$ montmorillonite at $25^{\circ} \mathrm{C}$ and 1 atmosphere (modified from Tardy, 1971).

limited by identifying mineral phases present, conserving electron transfer, maintaining isotope mass balance, and observing equilibrium thermodynamics.

In this study, a mass-balance approach using the U.S. Geological Survey computer programs WATEQF (Plummer and others, 1978) and BALANCE ${ }^{2}$ (Parkhurst and others, 1982) is used in developing geochemical models to define the relation between mineralogy and the observed water chemistry.

WATEQF is used to determine activities of dissolved chemical constituents and to calculate the saturation indexes (SI) of plausible mineral sources of and sinks for chemical constituents. The $S I$ indicates whether a mineral will be dissolving or precipitating in the water analyzed.

$$
S I=\log I A P / K
$$

where IAP is the ion-activity product of the mineral-water reaction and $K$ is the equilibrium constant for the mineralwater reaction. IF $S I$ is less than zero, the water is considered undersaturated with respect to the mineral and the mineral, if present, should be dissolving. If $S I$ equals zero, the water is considered in equilibrium with respect to the mineral. If $S I$ is greater than zero, the water is considered supersaturated with respect to the mineral and the mineral should be forming.

${ }^{2}$ BALANCE is so named because it maintains a mass balance within the chemical system.
BALANCE is used to quantify chemical reactions between ground water and sets of mineral phases. This program solves a set of simultaneous equations comprising a mass-balance equation for each constituent in the water analysis such that the number of constituents equals the number of phases. These equations ensure a mass balance in models presented so that no constituent is created or lost in the modeling process. According to Plummer and Back (1980), mass balance consists of the following relationship of $n$ equations:

$$
\sum_{\mathrm{j}=\mathrm{I}}^{\Phi} \alpha_{j} \beta_{c, j}=\left.\Delta m_{c}\right|_{c=\mathrm{I}, n}
$$

where $\Phi$ is the total number phases (minerals and gases) in the mass-balance reaction, $n$ is number of constituents in the water analysis, $\alpha_{j}$ is the coefficient of the $j$ th phase in the mass-balance reaction, $\beta_{c, j}$ is the stoichiometric coefficient of the $c$ th constituent in the $j$ th phase, and $\Delta m_{c}$ is the observed change in moles/kilograms $\mathrm{H}_{2} \mathrm{O}$ of the $c$ th constituent (final solution minus initial solution). If the number of constituents $(n)$ is less than the number of phases $(\Phi)$ (as in this study), there is no unique definition of the relation between phases and water chemistry, and multiple models must be examined.

Ideally, when constructing a geochemical reaction model, one would find a unique valid combination of minerals that, when reacted with water, will yield the observed water chemistry. Realistically, however, one can strive only to eliminate as many possibly valid combinations of phases as possible through the use of thermodynamic calculations

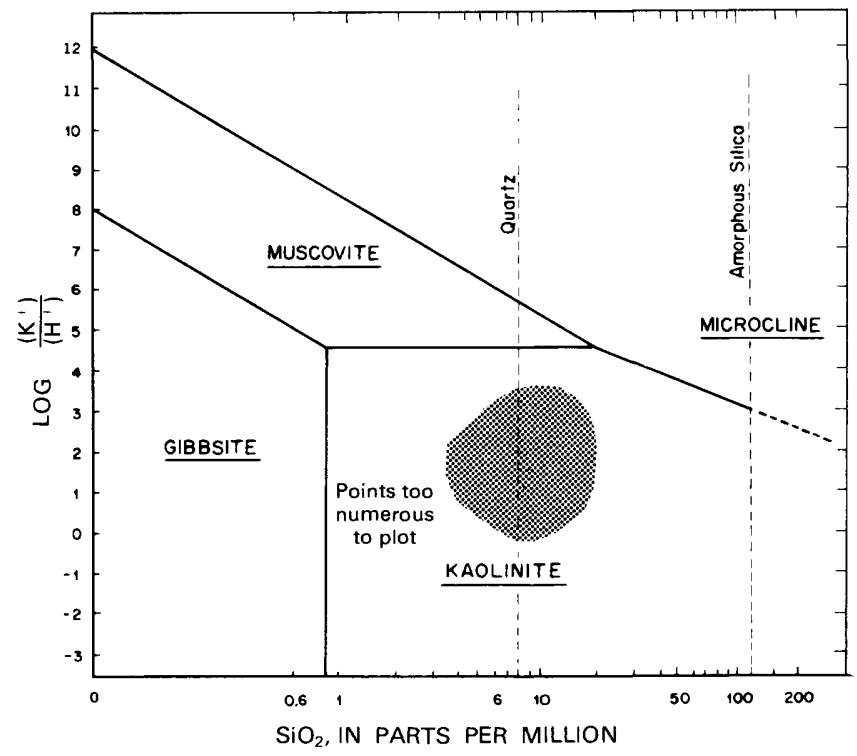

Figure 11. Relation of ground water sampled in the study area within the stability fields of muscovite, gibbsite, kaolinite, and microcline at $25^{\circ} \mathrm{C}$ and at 1 atmosphere (modified from Tardy, 1971). 
and isotope data. It is stressed that other models not considered in this study may represent the chemical system as well.

To investigate the possible chemical reactions taking place in ground water underlying the ridge, three sampling sites were selected for close examination. Water from a spring located near the ridgetop provides water chemistry from the recharge area. This water is used as the initial water in determining the effects of mineralogy on water chemistry as water moves downgradient away from the ridgetop. Water from a well finished in bedrock on the hillside reveals the effects on water that has passed through much of the

Table 2. Chemical analyses of water from the spring and wells used in geochemical reaction models.

$[\delta$, relative difference in concentration in per mil $(\% o)]$

\begin{tabular}{|c|c|c|c|}
\hline $\begin{array}{l}\text { Constituent } \\
\text { or parameter }\end{array}$ & $\begin{array}{c}\text { Ridgetop } \\
\text { spring (14ES3) }\end{array}$ & $\begin{array}{c}\text { Hillside } \\
\text { well }(14 \mathrm{E} 24) \\
\end{array}$ & $\begin{array}{c}\text { Valley } \\
\text { well (14E8) }\end{array}$ \\
\hline Calcium & 1.0 & 27.0 & 2.0 \\
\hline Magnesium & .8 & 7.3 & .5 \\
\hline Sodium & 1.9 & 18.0 & 53.0 \\
\hline Potassium & .7 & 1.3 & 1.5 \\
\hline Iron (dissolved) & .06 & .27 & .07 \\
\hline Aluminum & .03 & .0 & .03 \\
\hline Sulfate & 4.0 & 11.0 & 7.6 \\
\hline Chloride & .7 & 1.3 & 1.5 \\
\hline Fluoride & .1 & .2 & .2 \\
\hline Bicarbonate & 12.0 & 145.0 & 171.0 \\
\hline Silica & 16.0 & 15.0 & 10.0 \\
\hline $\mathrm{pH}$ & 6.3 & 7.2 & 7.6 \\
\hline Oxygen & 11.0 & $<.01$ & $<.01$ \\
\hline Methane & .0 & .5 & .5 \\
\hline $\begin{array}{l}\text { Temperature } \\
\text { (degrees Celsius) }\end{array}$ & 3.0 & 16.0 & 10.2 \\
\hline${ }^{13} \mathrm{C}(\% / 00)$ & $-18.35 \pm .2 \%$ & $-11.60 \pm .2 \%$ & $-10.50+.2 \%$ \\
\hline \multicolumn{4}{|c|}{$\begin{array}{l}{ }^{13} C_{\text {calcite sampled is }}-5.25 \pm .2 \% \text { relative to } P D \text { Belemnite } \\
{ }^{13} C_{\text {siderite sampled is }}+5.75+.2 \% \text { relative to } P D \text { Belemnite }\end{array}$} \\
\hline
\end{tabular}


strata within the ridge. Water from a well finished in bedrock in the valley demonstrates the effects of water flowing through the entire stratigraphic column.

Chemical data for the ridgetop spring and the hillside and valley wells are given in table 2 . Also included in table 2 are the $\delta^{13} \mathrm{C}$, gas composition, and water temperature. The redox state $(R S)$ is a means of keeping track of electron transfer in redox reactions

$$
R S=\sum_{\mathrm{i}}^{1} v_{i} m_{i}
$$

where $I$ is the total number of species in solution, $m_{i}$ is the molality of the $i$ th species in solution, and $\nu_{i}$ is the operational valence of the species. For a detailed discussion of operational valence, see Plummer and others (1983). Redox state $(R S)$ values for each water are given in table 3 .
The results of speciation calculations by WATEQF (Plummer and others, 1978) are also shown in table 3. Included are saturation indexes for selected minerals shown dissolving or forming in the models proposed.

Plausible phases for inclusion in geochemical reaction models are selected from mineralogical analyses (table 14) of rock from core hole 2 (figs. 2, and 3). Six sets of phases considered possible models in this study are shown in table 4. 1n all six sets of phases, potassium in the water is derived from K-feldspar, magnesium from chlorite, and silica from $\mathrm{K}$-feldspar and chlorite. Silica is precipitated as chalcedony and kaolinite, and aluminum is precipitated as kaolinite.

ln addition to these phases common to all models presented, combinations of other phases, which provide sources of sodium and source/sinks of calcium, are included. In phase sets 1 and 4, sodium in the water is derived from plagioclase while calcium comes from both plagioclase and calcite. In phase sets 2 and 5 , sodium is derived

Table 3. Results of speciation calculations using WATEQF.

[Data in millimoles]

\begin{tabular}{lccc}
$\begin{array}{l}\text { Constituent } \\
\text { or parameter }\end{array}$ & $\begin{array}{c}\text { Ridgetop } \\
\text { spring }\end{array}$ & $\begin{array}{c}\text { Hillside } \\
\text { well }\end{array}$ & $\begin{array}{r}\text { Valley } \\
\text { well }\end{array}$ \\
\hline Calcium & .0250 & .6738 & .0499 \\
Magnesium & .0329 & .3003 & .0206 \\
Sodium & .0826 & .7831 & 2.3059 \\
Potassium & .0179 & .0325 & .0384 \\
Iron (dissolved) & .0011 & .0048 & .0013 \\
Aluminum & .0011 & .0000 & .0011 \\
Silica & .2663 & .2497 & .1665 \\
Sulfur & .0416 & .1145 & .0791 \\
Carbon (total) & .5306 & 2.7328 & 2.9889 \\
Redox state & 2.4933 & 11.6344 & 12.4898 \\
Saturation index: & & & -1.4695 \\
$\quad$ Calcite & -4.2452 & -.7412 & -27.7489 \\
Siderite & -13.9210 & -26.5616 & 8.4094 \\
Goethite & 6.7731 & 9.0975 & \\
& & &
\end{tabular}


Table 4. Selected sets of plausible phases for mass-balance calculations

\section{Plagioclase, calcite, potassium feldspar, chlorite, silica, kaolinite, pyrite, goethite, carbon cioxide, oxygen}

2 Plagioclase, cation exchange, potassium feldspar, chlorite, silica, kaolinite, pyrite, goethite, carbon dicixide, oxygen

3 Ion exchange, calcite, potassium feldspar, chlorite, silica, kaolinite, pyrite, goethite, carbon dioxide, oxygen

4 Plagioclase, calcite, potassium feldspar, chlorite, silica, kaolinite, pyrite, goethite, siderite, oxygen

5 Plagioclase, cation exchange, potassium feldspar, chlorite, silica, kaolinite, pyrite, goethite, siderite, oxygen

6 Cation exchange, calcite, potassium feldspar, chlorite, silica, kaolinite, pyrite, goethite, siderite, oxygen

from both plagioclase and cation exchange while calcium comes from plagioclase and is lost through cation exchange. In phase sets 3 and 6 , sodium is derived from cation exchange while calcium comes from calcite and is lost through cation exchange.

In phase sets 1, 2, and 3, dissolved iron is derived from pyrite while carbon comes from carbon dioxide gas. In phase sets 4,5 , and 6 , dissolved iron is derived from both siderite and pyrite while carbon comes from siderite only. To model the ground-water chemistry, all phase sets must be considered and more than one may be plausible.

In the models presented, the concentration of sulfate indicates the amount of pyrite that has oxidized and thereby defines the contribution of pyrite to the dissolved iron concentration. During the oxidation of pyrite, 1 mole of iron is produced for every 2 moles of sulfate ion produced.

\section{Ridgetop Spring}

Discharge from spring 14ES3 at an altitude of 2,540 feet above sea level is typical of ground water flowing from springs located near the top of the ridge and represents water nearest the recharge area. In modeling chemical reactions in the ridgetop, water from the spring is considered the final water and pure water is the initial water for mass-balance calculations. Table 5 presents the results of mass-balance calculations using the phase sets (table 4) appropriate for the
Table 5. Results of reaction model mass-balance calculations for the ridgetop spring

[Values are in millimoles per kilogram of water. A positive value indicates dissolution of the phase; a negative value indicates formation of the phase]

\begin{tabular}{lccc}
\hline $\begin{array}{c}\text { Plausible } \\
\text { phase }\end{array}$ & \multicolumn{3}{c}{ Reaction mode } \\
\cline { 2 - 4 } Plagioclase & .1180 & \multicolumn{1}{c}{2} & \multicolumn{1}{c}{3} \\
Calcite & -.0104 & .0663 &.-1 \\
Cation exchange & $-\ldots$ & .0413 & .0056 \\
Potassium feldspar & .0179 & .0179 & .0179 \\
Chlorite & .0066 & .0066 & .0066 \\
Silica & .0577 & .2229 & .0801 \\
Kaolinite & -.0917 & -.0150 & -.0813 \\
Pyrite & .0208 & .0208 & .0208 \\
Carbon dioxide & .5705 & .4938 & .5601 \\
Goethite & -.0197 & -.0197 & -.0197 \\
Oxygen & .0781 & .0781 & .0781 \\
\hline
\end{tabular}


springwater. Each numbered column is a separate reaction model. The numbers in the columns indicate the amount of each phase $\left(\alpha_{\mathrm{j}}\right)$ in moles $\times 10^{-3}$ (millimoles) entering the water $(+)$ or leaving the water $(-)$ per kilogram of water.

Models 2 and 3 are consistent with calculated saturation indexes in table 3 , and both may accurately represent the chemical system. The more likely situation is that some combination of both is required. Relative contributions of the two models cannot be defined with the data available. Model 1 is disregarded because it requires the precipitation of calcite and, according to WATEQF, the water is undersaturated with respect to calcite. Siderite is not considered a sourse of carbon to the springwater because siderite is not present in the strata near the ridgetop and is therefore not included in the reaction models for the spring.

\section{Hillside Well}

To define the effect of rock strata on water passing farther down through the strata, the water from the spring
(14ES3). located near the top of the ridge, is used as the initial water. Water from well 14E24 (figure 3), located on the side of the ridge at an altitude of 2,100 feet above sea level, is used as the final water. Table 6 provides results of mass-balance calculations according to speciationcalculation results (table 3 ) for each of the six phase sets shown in table 4. Models 1, 3, 4, and 6 are thermodynamically valid, and any one or combination of more than one may represent the system. Models 2 and 5 are disregarded because they require that ion exchange be a source of calcium and a sink for sodium. Cation exchange is thought to be a source of sodium and a sink for calcium since divalent cations bond more strongly to exchange sites than monovalent cations. The activity of sodium increases along the flow path, while the activity of calcium decreases, which further supports the idea of cation exchange. This is shown by the following relation:

$$
\mathrm{Ca}^{2+}+2 \mathrm{Na}^{+}{ }_{\mathrm{ex}}=\mathrm{Ca}^{2+}{ }_{\mathrm{ex}}^{+}+2 \mathrm{Na}^{+} \text {. }
$$

Table 6. Results of reaction model mass-balance calculations for the hillside well

[Values are in millipores per kilogram of water. A positive value indicates dissolution of the phase; a negative value indicates formation of the phase]

\begin{tabular}{|c|c|c|c|c|c|c|}
\hline \multirow{2}{*}{$\begin{array}{c}\text { Plausible } \\
\text { phase }\end{array}$} & \multicolumn{5}{|c|}{ Reaction model } & \multirow[b]{2}{*}{6} \\
\hline & 1 & 2 & 3 & 4 & 5 & \\
\hline Plagioclase & 1.0007 & 1.5370 & -- & 1.0007 & 1.8165 & --- \\
\hline Calcite & .3486 & --- & .9991 & .4487 & --- & .9991 \\
\hline Cation exchange & -- & -.1877 & .3503 & -- & -.2855 & .3503 \\
\hline $\begin{array}{l}\text { Potassium } \\
\text { feldspar }\end{array}$ & .0154 & .0154 & .0154 & .0154 & .0154 & .0154 \\
\hline Chlorite & .0535 & .0535 & .0535 & .0535 & .0535 & .0535 \\
\hline Silica & -1.5009 & -2.2517 & -.0999 & -1.5009 & -2.6429 & -.0999 \\
\hline Kaolinite & -.7121 & -1.0607 & -.0617 & -.7121 & -1.2424 & -.0617 \\
\hline Pyrite & .0365 & .0365 & .0365 & .0365 & .0365 & .0365 \\
\hline Carbon dioxide & 1.8238 & 2.1724 & 1.1734 & -- & --- & -- \\
\hline Siderite & --- & -- & -- & 1.7237 & 2.1724 & 1.1734 \\
\hline Goethite & -.0363 & -.0363 & -.0363 & -1.7560 & -2.2087 & -1.2096 \\
\hline 0xygen & .1366 & .1366 & .1366 & .5676 & .6797 & .4300 \\
\hline
\end{tabular}


Further reduction in the number of valid models can be accomplished if both sources of carbon $\left(\mathrm{CO}_{2}\right.$ and siderite) are included in the same model. This, however, can be done only if the relative contributions of the two carbon sources can be calculated. Knowledge of the $\delta^{13} \mathrm{C}$ of soil gas, siderite, calcite, and ground water satisfies this requirement. The $\delta^{13} \mathrm{C}$ values for calcite, siderite, and water samples were determined from samples collected in the study area, and values are provided in table 2 .

Accurate values for $\delta^{13} \mathrm{C}$ of soil gas are particularly difficult to obtain. These values change dramatically with the changing seasons and corresponding changes in temperatures, soil moisture, and plant growth activity (Rightmire, 1978). In this study, the $\delta^{13} \mathrm{C}$ for $\mathrm{CO}_{2}$ entering the ground water is calculated on the basis of the observed $\delta^{13} \mathrm{C}$ of the springwater. This calculation is accomplished using a massbalance approach which determines the $\delta^{13} \mathrm{C}$ in the soil gas required to give the springwater its observed $\delta^{13} \mathrm{C}$ value. The calculation is as follows:

$$
\begin{aligned}
& \delta^{13} \mathrm{C} \text { of } \mathrm{CO}_{2}= \\
& \frac{\left(\text { total carbon } \times \delta^{13} \mathrm{C}_{\text {springwater }}\right)-\left(\Delta_{\text {calcite }} \times \delta^{13} \mathrm{C}_{\text {calcite }}\right)}{\Delta \mathrm{CO}_{2}},
\end{aligned}
$$

where $\Delta \mathrm{CO}_{2}$ is the amount of $\mathrm{CO}_{2}$ entering the water in model 2 (table 5) and $\Delta_{\text {calcite }}$ is the amount of calcite dissolving in model 2 (table 5). If calculations are made on the basis of model 3 (table 5), the other valid model for the spring, the $\delta^{13} \mathrm{C}$ of $\mathrm{CO}_{2}$ entering the system would be identical to that found in the water because $\mathrm{CO}_{2}$ is the only source of carbon for model 3 (table 5). In model 2 (table 5), calcite $\left(\delta^{13} \mathrm{C}=-5.25 \% 0\right)^{3}$ is dissolved and calculations yield a lower value for $\delta^{13} \mathrm{C}$ for $\mathrm{CO}_{2}$ gas. Because of the presence and high reactivity of calcite, this lower value $(-20.1 \%)$ is considered the more realistic value.

The relation between the $\delta^{13} \mathrm{C}$ of the ground water in the hillside well and the amounts of each phase dissolving, including the two carbon sources, is as follows:

$$
\begin{aligned}
& \delta^{13} \mathrm{C}_{\text {ground water }}= \\
& \frac{\left(\Delta_{\text {calcite }} \times-5.25\right)+\left(\Delta_{\text {siderite }} \times+5.75\right)+\left(\Delta_{\mathrm{CO}_{2}} \times-20.1\right)}{\mathrm{C}_{\text {total }}}
\end{aligned}
$$

where $\Delta_{\text {calcite }}, \Delta_{\text {siderite }}$, and $\Delta_{\mathrm{CO}_{2}}$ are the amounts of each phase entering the ground water.

Table 7 gives data for the reaction models calculated by means of carbon isotope data. These models reduce the number of models by simultaneously including both sources

\footnotetext{
${ }^{3}$ The symbol $\delta$ indicates the relative difference in concentration, in units of per mil (\%o). $\delta^{13} \mathrm{C}=$ (Ratio of sample/Ratio of standard -1$) \times 1,000$. The standard used is the PD Belemnite.
}

Table 7. Results of reaction model mass-balance calculations for the hillside well using carbon-13 data

[Values are in millimoles per kilogram of water. A positive value indicates dissolution of the phase; a negative value indicates formation of the phasel

\begin{tabular}{lccr}
\hline $\begin{array}{c}\text { Plausible } \\
\text { phase }\end{array}$ & \multicolumn{3}{c}{ Reaction model } \\
\cline { 2 - 4 } Plagioclase & 1.0007 & \multicolumn{1}{c}{8} & \multicolumn{1}{c}{9} \\
Calcite & .3460 & .9991 & -.5370 \\
Cation exchange & --- & .3503 & -.1877 \\
Potassium & & & \\
feldspar & .0154 & .0154 & .0154 \\
Chlorite & .0535 & .0535 & .0535 \\
Silica & -1.5009 & -.0999 & -2.2517 \\
Kaolinite & -.7121 & -.0617 & -1.0607 \\
Pyrite & .0365 & .0365 & .0365 \\
Carbon dioxide & .3088 & .0320 & .4571 \\
Siderite & 1.5150 & 1.1414 & 1.7153 \\
Goethite & -1.5513 & -1.1776 & -1.7515 \\
Oxygen & .5154 & .4220 & .5654 \\
\hline
\end{tabular}

of carbon (siderite and $\mathrm{CO}_{2}$ ). Model 9 is disregarded because it requires that ion exchange be a source of calcium and a sink for sodium. The number of valid models is now condensed to two. Model 7 derives much of the calcium and all the sodium from plagioclase. Model 8 derives all the calcium from calcite and all the sodium from ion exchange. The abundance of plagioclase in the rock supports model 7 , whereas the solubility of calcite and the abundance of clay and carbonaceous material for ion exchange in the rock support model 8 . Both models are thermodynamically valid, and some combination of the two probably best represents the system. The relative contributions of the two, however, cannot be defined by the available data.

\section{Valley Well}

Water representing the end of the local flow system is from well 14E8 (figure 3), located in the valley at a landsurface elevation of 1,800 feet. Water from the ridgetop spring (14ES3) is used as the initial solution in models presented. Table 8 provides results of mass-balance calculations for each of the phase sets presented in table 4 . Results of speciation calculations for water from the valley well (table 3) are used in these models. 
Table 8. Results of reaction model mass-balance calculations for the valley well

[Values are in millipores per kilogram of water. A positive value indicates dissolution of the phase: a negative value indicates formation of the phase]

\begin{tabular}{|c|c|c|c|c|c|c|}
\hline \multirow{2}{*}{$\begin{array}{c}\text { Plausible } \\
\text { phase }\end{array}$} & \multicolumn{6}{|c|}{ Reaction model } \\
\hline & 1 & 2 & 3 & 4 & 5 & 6 \\
\hline Plagioclase & 3.1763 & 1.7486 & --- & 3.1763 & 1.7486 & --- \\
\hline Calcite & -.9280 & -- & 1.1366 & -.9280 & -- & 1.1366 \\
\hline Cation exchange & -- & .4997 & 1.1117 & --- & .4997 & 1.1117 \\
\hline $\begin{array}{l}\text { Potassium } \\
\text { feldspar }\end{array}$ & .0205 & .0205 & .0205 & .0205 & .0205 & .0205 \\
\hline Chlorite & -.0025 & -.0025 & -.0025 & -.0255 & -.0025 & -.0025 \\
\hline Silica & -4.5852 & -2.5865 & -.1384 & -4.5852 & -2.5865 & -.1384 \\
\hline Kaolinite & -2.0723 & -1.1443 & -.0074 & -2.0723 & -1.1443 & -.0074 \\
\hline Pyrite & .0188 & .0188 & .0188 & .0188 & .0188 & .0188 \\
\hline Carbon dioxide & 3.3717 & 2.4437 & 1.3071 & --- & -- & -- \\
\hline Siderite & --- & -- & -- & 3.3717 & 2.4437 & 1.3071 \\
\hline Goethite & -.0199 & -.0199 & -.0199 & -3.3915 & -2.4636 & -1.3270 \\
\hline Oxygen & .0702 & .0702 & .0702 & .9132 & .6812 & .3970 \\
\hline
\end{tabular}

Models 1 and 4 are disregarded because they require the precipitation of calcite, and, according the WATEQF, the water is undersaturated with respect to calcite. This narrows the number of plausible models to four. To further reduce the list, as with the hillside well, stable carbon isotope data are used.

Table 9 presents the results when carbon isotope data were included in the mass-balance calculations. The number of valid models is reduced to three by combining both sources of carbon (siderite and $\mathrm{CO}_{2}$ ). Model 9 is disregarded because it requires the precipitation of calcite, and, according to WATEQF, the water is undersaturated with respect to calcite. The system is probably best represented by a combination of models 7 and 8 . The relative contribution of these two models is not defined. All models show chlorite to be precipitating. Although this is not likely, thermodynamically, magnesium is probably being removed from the ground water by cation exchange, or by entering the crystal lattice of a clay phase that may be forming.

\section{EVOLUTION OF WATER CHEMISTRY IN THE NORTON FORMATION}

Water enters the ridge, reacts with plagioclase, chlorite, calcite, pyrite, and siderite, and leaches $\mathrm{Ca}^{2+}, \mathrm{Mg}^{2+}$, $\mathrm{Na}^{+}, \mathrm{SO}_{4}{ }^{2-}, \mathrm{HCO}_{3}{ }^{-}$, and $\mathrm{Fe}^{2+}$ from the minerals present. Under oxidizing conditions, the iron precipitates as a ferric hydroxide on rock surfaces. This solid phase is readily seen in core samples containing the upper weathered zone or containing fractures through which water has traveled. The net result is a moderately hard calcium-magnesium bicarbonate water. If the concentration of iron sulfides in the rock were greater, one would expect a calcium-magnesium sulfate water, like that found in springs flowing from strata associated with coal seams (Rogers and Powell, 1983).

Water passing down through the strata to the lower altitudes is affected by cation exchange, removing calcium and, perhaps, magnesium and yielding a soft sodium bicarbonate water. The removal of calcium and magnesium from 
Table 9. Results of reaction model mass-balance calculations for the valley well using carbon-13 data.

[Values are in millimoles per kilogram of water. A positive value indicates dissolution of the phase; a negative value indicates formation of the phase]

\begin{tabular}{lccc}
\hline $\begin{array}{l}\text { Plausible } \\
\text { phase }\end{array}$ & \multicolumn{3}{c}{ Reaction model } \\
\cline { 2 - 4 } Plagioclase & --- & 8 & \multicolumn{1}{c}{9} \\
Calcite & 1.1366 & -.7486 & 3.1763 \\
Cation exchange & 1.1117 & .4997 & -.9280 \\
$\begin{array}{l}\text { Potassium } \\
\text { feldspar }\end{array}$ & .0205 & .0205 & --- \\
Chlorite & -.0025 & -.0025 & -.0025 \\
Silica & -.1384 & -2.5865 & -4.5852 \\
Kaolinite & -.0077 & -1.1443 & -2.0723 \\
Pyrite & .0188 & .0188 & .0188 \\
Carbon dioxide & .0284 & .4941 & .8743 \\
Siderite & 1.2787 & 1.9496 & 2.4974 \\
Goethite & -1.2985 & -1.9695 & -2.5173 \\
Oxygen & .3899 & .5576 & .6960 \\
\hline
\end{tabular}

the system can be seen by comparing the values for calcium and magnesium in table 3 for the hillside well and the valley well. Acidity produced by oxidation of pyrite (reaction 13) is buffered by $\mathrm{HCO}_{3}{ }^{-}$produced by the reaction of $\mathrm{CO}_{2}$ with plagioclase (reaction 2) and the dissolution of calcite (reaction 6).

Furthermore, water in the deeper strata becomes deficient in oxygen. Thus, iron and sulfate may be removed from ground water by formation of iron-sulfide minerals. This is seen in the water analysis (table 3 ) where the activities of iron and sulfate in the downgradient valley well are lower than those in the hillside well. A slight odor of hydrogen-sulfide gas in the valley well indicates that some sulfate may be reduced to form hydrogen-sulfide gas. Methane gas found in the ground water is thought to originate in the underlying Mississippian strata known to contain methane. It is possible, however, that some methane is produced in the ground water under reducing conditions. Further work is required to identify the sources of the gases.

\section{COMPARISON OF WATER CHEMISTRY WITHIN UNMINED AND MINED BASINS}

The study area includes both a mined and an unmined small basin (fig. 5). Because ground water is not available from wells in the previously mined basin, a technique is presented in this study that uses quality of water from low base flows. This approach attempts to show the changes in reactions that occur as a result of disturbance by mining.

Chemical data for water collected at sampling sites in unmined Grissom Creek and mined Barton Fork basins (figure 5) are provided in table 10 . The results of speciation calculations are shown in table 11. Stable-isotope data are not available for water from Grissom Creek or Barton Fork to define the role of siderite in models. The amount of dissolved iron in the water does not exceed that attributable to pyrite oxidation $\left(\Delta \mathrm{Fe}^{2+} \leq \Delta \mathrm{SO}_{4}{ }^{2-}\right)$; therefore, omission of siderite from the models causes no significant problems such as dissolution of goethite as a source of iron that cannot be attributed to pyrite.

To assess the overall effects of weathering reactions on water within the unmined Grissom Creek basin and the mined Barton Fork basin, water samples were collected at low flow. Grissom Creek drains an area of 2.8 square miles. The water collected represents an integration of all ground water flowing from the strata in the Grissom Creek basin.

Barton Fork drains a basin of 1.2 square miles; 20 percent of the basin has been disturbed by surface mining since 1970. There appears to have been no attempt at reclamation. The water collected at low flow represents an integration of all ground water flowing from the strata within the Barton Fork basin.

Results of mass-balance calculations using results of speciation calculations for Grissom Creek and Barton Fork at low flow are presented in table 12. Pure water is used as

Table 10. Analytical data for low flow in Grissom Creek (unmined) and Barton Fork (mined)

[Values are in milligrams per liter]

\begin{tabular}{lcc}
\hline $\begin{array}{l}\text { Constituent } \\
\text { or parameter }\end{array}$ & Grissom Creek & Barton Fork \\
\hline Calcium & 19.0 & 28.0 \\
Magnesium & 8.4 & 12.0 \\
Sodium & 6.8 & 12.0 \\
Potassium & 3.0 & 2.9 \\
Iron (dissolved) & .02 & .01 \\
Aluminum & .001 & .001 \\
Sulfate & 9.1 & 68.0 \\
Chloride & 7.8 & 6.0 \\
Bicarbonate & 90.2 & 80.0 \\
Silica & 8.0 & 8.0 \\
pH & 8.0 & 7.7 \\
Temperature & & 20.0 \\
\hline
\end{tabular}


the initial water and samples at low flow are used as the final water. Both models 1 and 3 are thermodynamically valid. Model 2 is disregarded because it requires ion exchange to be a source of calcium and a sink for sodium.

A comparison of the amounts of mineral weathering of selected phases in the unmined and mined basins as tabulated in table 13 shows the chemical increases that occur in the mined basin as a result of surface-mining activities. The amount of weathering is shown as the amount of mineral phase dissolved in the water per kilogram of water. There is a dramatic change in the relative amount of each mineral listed.

The increase in the amount of weathering of minerals demonstrates the effect of increased mineral-surface area resulting from surface-mining activities. The increase in storage capacity of the host material and the corresponding increase in residence time for the ground water also contribute to the differing amounts of weathering observed in the two basins. The 647 percent increase in pyrite weathering is by far the largest increase among weathering reactions. The slight depression of the $\mathrm{pH}$ in Barton Fork (table 10 ) indicates that the buffering capacity present is sufficient to neutralize the acidity produced by the concentration of reactive pyrite present in the strata involved.

\section{EFFECTS OF MINES ON GROUND-WATER QUALITY}

The dramatic increase in pyrite weathering suggested by mass balance in the mined basin indicates that deterioration of water quality may occur from mining practices. A question to be addressed is, To what extent can the water quality be affected? With the computer model PHREEQE ${ }^{4}$ (Parkhurst and others, 1982), it is possible to carry out the geochemical processes obtained from the mass-balance calculations to some evolutionary limits. In this case, formation of gypsum $\left(\mathrm{CaSO}_{4} \cdot 2 \mathrm{H}_{2} \mathrm{O}\right)$ and calcite $\left(\mathrm{CaCO}_{3}\right)$ saturation are considered the controls limiting the activities of calcium and sulfate.

In the reaction model, if one (1) begins with chemically pure water, (2) allows the water to equilibrate with the atmosphere before reacting with the mineralogy, (3) allows an unlimited amount of oxygen to enter the system, (4) allows an unlimited amount of time to pass, (5) chooses a temperature of $20^{\circ} \mathrm{C}$., and (6) allows the weathering reactions to take place until the water is saturated with respect to gypsum, calcite, goethite, and pyrite, then the activity of calcium will reach 18.52 millimoles per kilogram ( 745 milligrams per liter), sulfate will reach 13.33 millimoles per

\footnotetext{
${ }^{4}$ PHREEQE is an acronym for $\mathrm{pH}-$ Redox Equilibrium Equations.
}

Table 11. Results of speciation calculations using WATEQF for low flow in Grissom Creek (unmined) and Barton Fork (mined)

[Values are in millimoles]

\begin{tabular}{lcc}
\hline $\begin{array}{l}\text { Constituent } \\
\text { or parameter }\end{array}$ & Grissom Creek & Barton Fork \\
\hline Calcium & .4741 & .6988 \\
Magnesium & .3456 & .4937 \\
Sodium & .2958 & .5221 \\
Potassium & .0767 & .0742 \\
Iron (dissolved) & .0004 & .0002 \\
Aluminum & .0000 & .0000 \\
Silica & .1332 & .1332 \\
Sulfur & .0947 & .7080 \\
Carbon (total) & 1.5218 & 1.3557 \\
Redox state & 6.6566 & 9.6714 \\
Saturation index: & & \\
Calcite & -.2391 & -.4661 \\
Siderite & -29.0593 & -28.8509 \\
Goethite & 8.5221 & 8.2277 \\
\hline
\end{tabular}

kilogram (1,280 milligrams per liter), and iron will reach 0.003 millimoles per kilogram (I67 micrograms per liter). All these conditions can be met by an unreclaimed spoils pile. Three important water-quality parameters-sulfate content, hardness, and dissolved solids content-will be increased beyond recommended limits.

This scenario, however, does not include the effects of cation exchange on water chemistry. With the introduction of cation exchange, calcium is removed and replaced by sodium and equilibrium with respect to calcite is disrupted. As long as ion exchange can remove calcium from the water, calcite dissolution will continue unhindered. The result of this process is a water rich in sodium, deficient in calcium, rich in bicarbonate, and high in dissolved solids. The activities of dissolved constituents in the final solution will be limited by the availability of calcite and the cation exchange capacity of the ion exchange material present.

If oxygen were depleted in the ground water below the recharge area, which would yield a reducing environment, iron and sulfate levels would be lowered. Iron may be precipitated as iron sulfide. Sulfate may be depleted by the formation of iron sulfides or hydrogen-sulfide gas. In a reducing environment with high bicarbonate activity, dissolved ferrous iron may be lost through the precipitation of siderite. 
Table 12. Results of mass-balance calculations for low flow in Grissom Creek (unmined) and Barton Fork (mined)

[Values are in millimoles per kilogram of water. A positive value indicates dissolution of the phase; a negative value indicates formation of the phase]

\begin{tabular}{|c|c|c|c|c|c|c|}
\hline \multirow{3}{*}{$\begin{array}{c}\text { Plausible } \\
\text { phase }\end{array}$} & \multicolumn{6}{|c|}{$\begin{array}{l}\text { Reaction model } \\
\text { Grissom Creek }\end{array}$} \\
\hline & \multicolumn{3}{|c|}{ Grissom Creek } & \multicolumn{3}{|c|}{ Barton Fork } \\
\hline & 1 & 2 & 3 & 1 & 2 & 3 \\
\hline Plagioclase & .4226 & .9569 & -- & .7457 & 1.4769 & --- \\
\hline Calcite & .3473 & --- & .6220 & .4753 & $\cdots$ & .9600 \\
\hline Ion exchange & --- & -.1870 & .1479 & --- & -.2559 & .2610 \\
\hline Potassium feldspar & .0767 & .0767 & .0767 & .0742 & .0742 & .0742 \\
\hline Chlorite & .0691 & .0691 & .0691 & .0988 & .0988 & .0988 \\
\hline Silica & -.6809 & -1.4290 & -.0893 & -1.1578 & -2.1815 & -.1138 \\
\hline Kaolinite & -.3821 & -.7295 & -.1075 & -.6205 & -1.0958 & -.1358 \\
\hline Pyrite & .0474 & .0474 & .0474 & .3540 & .3540 & .3540 \\
\hline Carbon dioxide & 1.1745 & 1.5218 & .8998 & .8807 & 1.3560 & .3960 \\
\hline Goethite & -.0470 & -.0470 & -.0470 & -.3540 & -.3540 & -.3540 \\
\hline Oxygen & .1776 & .1776 & .1776 & 1.3273 & 1.3273 & 1.3273 \\
\hline
\end{tabular}

\section{SUMMARY AND CONCLUSIONS}

The Norton Formation of Buchanan County, Va., is composed of deltaic, and lagoonal, nonmarine sediments. Strata observed in five cores within the Norton Formation demonstrate that the strata of the study area are composed of sandstone, siltstone, shale, clay, and coal. Predominant minerals include quartz, plagioclase feldspar, potassium feldspar, muscovite, chlorite, siderite, and calcite. Sulfur content of the rock is generally very low, less than 0.1 percent.

Water contacting reactive minerals is affected by hydrolysis of the silicates, dissolution of carbonates, oxidation of pyrite, and cation exchange. The interaction of the mineralogy and ground water is modeled using the mass-balance approach, which uses the U.S. Geological Survey computer programs WATEQF and BALANCE. Carbon-isotope data allow the inclusion of more than one carbon source in a model, reducing the number of possible models from six to three. The three reaction models developed account for the observed water chemistry. The models derive sulfate from pyrite, iron from pyrite and siderite, calcium from plagioclase and calcite, sodium from plagioclase and cation exchange, magnesium from chlorite, and carbon from carbon dioxide, calcite, and siderite. A moderately hard calciummagnesium bicarbonate water is found within the upper

Table 13. Comparison of mineral weathering in millimoles per kilogram of water in unmined and mined basins based on models 1 and 3 , table 12 .

[Values are in millimoles per kilogram of water]

\begin{tabular}{lccc}
$\begin{array}{l}\text { Phase that is } \\
\text { weathering }\end{array}$ & $\begin{array}{c}\text { Wined } \\
\text { basin }\end{array}$ & $\begin{array}{c}\text { Unmined } \\
\text { basin }\end{array}$ & $\begin{array}{c}\text { Increase in } \\
\text { weathering (in percent) }\end{array}$ \\
\hline Plagioclase & .7457 & .4226 & 76 \\
Calcite & .4753 & .3473 & 37 \\
& .9600 & .6220 & 54 \\
Chlorite & .0988 & .0691 & 43 \\
Pyrite & .3540 & .0474 & 647 \\
Cation exchange & .2610 & .1479 & 76 \\
\hline
\end{tabular}


strata. Water passing down through the strata to the lower altitudes is affected by cation exchange, yielding a soft sodium bicarbonate water.

In the upper strata where oxygen is present in the water, pyrite oxidizes to release dissolved ferrous and sulfate ions. In the lower strata where oxygen is lacking in the water, pyrite appears to be precipitating.

A comparison of water quality in adjacent unmined and mined basins reveals dramatic increases in the amounts of minerals weathering. The effects of surface mining activities appear to increase the rate of pyrite oxidation over 600 percent relative to the rate of weathering in the unmined basin.

Using the U.S. Geological Survey computer program PHREEQE, the geochemical processes were allowed to proceed until precipitation of gypsum and calcite limited the activities of calcium and sulfate. In this process, three important water quality parameters - sulfate content, hardness, and dissolved solids content-will be increased beyond the limits for drinking water recommended by the Environmental Protection Agency (1973).

\section{SELECTED REFERENCES}

Epps, S.R., 1978, Buchanan County ground water: Present conditions and prospects: Virginia State Water Control Board Bulletin $311,75 \mathrm{p}$.

Freeze, R.A., and Cherry, J.A., 1979, Groundwater: Englewood, N.J., Prentice-Hall, 604 p.

Hinds, Henry, 1918, The geology and coal resources of Buchanan County, Virginia: Virginia Geological Survey Bulletin XVIII, $278 \mathrm{p}$.

Miller, R.L., and Meissner, C.R., Jr., 1977, Geologic map of Big A Mountain quadrangle, Buchanan and Russell counties, Virginia: U.S. Geological Survey Geologic Quadrangle Map GQ-1350, scale 1:24,000.

Paces, Thomas, 1973, Steady-state kinetics and equilibrium between ground water and granitic rocks: Geochimica et Cosmochimica Acta, v. 37, no. 12, p. 2640-2661.

Parkhurst, D.L., Plummer, L.N., and Thorstenson, D.C., 1982, BALANCE; computer program for calculating mass transfer for geochemical reactions in ground water: U.S. Geological Survey Water-Resources Investigations Report 82-14, 33 p.

Parkhurst, D.L., Thorstenson, D.C., and Plummer, L.N., 1980, PHREEQE-A computer program for geochemical calculations: U.S. Geological Survey Water-Resources Investigations Report 80-96, 216 p.

Plummer, L.N., and Back, William, 1980, The mass balance approach: Application to interpreting the chemical evolution of hydrologic systems: American Journal of Science, v. 280, no. 2 , v. 280 , no. 2 , p. $130-142$.

Plummer, L.N., Jones, B.F., and Truesdell, A.H., 1978, WATEQF: A FORTRAN IV version of WATEQ, a computer program for calculating chemical equilibrium of natural waters: U.S. Geological Survey Water-Resources Investigations Report 76-13, 66 p.

Plummer, L.N., Parkhurst, D.L., and Thorstenson, D.C., 1983, Development of reaction models for ground-water systems: Geochimica et Cosmochimica Acta, v. 47, no. 4, p. 665686.

Reyes-Navarro, J., and Davis, A., 1976, Pyrite in coal: Its forms and distribution as related to the environment of coal deposition in three selected coals from western Pennsylvania: University Park, Pennsylvania State University, Special Research Report SR-110.

Rightmire, C.T., 1978, Seasonal variation in $\mathrm{P}_{\mathrm{CO}_{2}}$ and ${ }^{13} \mathrm{C}$ content of soil atmosphere: Water Resources Research, v. 14, no. 4, p. 691-692.

Rogers, S.M., and Hufschmidt, P.W., 1980, Quality of surface water in the coal mining area of southwest Virginia: U.S. Geological Survey Water-Resources Investigations Open-File Report 80-769, 2 sheets.

Rogers, S.M., and Powell, J.D., 1983, Quality of ground water in southern Buchanan County, Virginia: U.S. Geological Survey Water-Resources Investigations Report 82-4022, 36 p.

Singer, P.C., and Stumm, Werner, 1968, Kinetics of the oxidation of ferrous iron: Symposium on Coal Mine Research, 2d, Pittsburgh, Pa. (Mellon Institute) 1968, p. 12-33.

Tardy, Yves, 1971, Characterization of principal weathering types by the geochemistry: Chemical Geology, vol. 7, p. 253-271.

Thorstenson, D.C., Fisher, D.W., Croft, M.G., 1979, The geochemistry of the Fox Hills-basal Hells Creek aquifer in southwestern North Dakota and northwestern South Dakota: Water Resources Research, v. 15, no. 6, p. 1479-1498. 
TABLES 14-16 


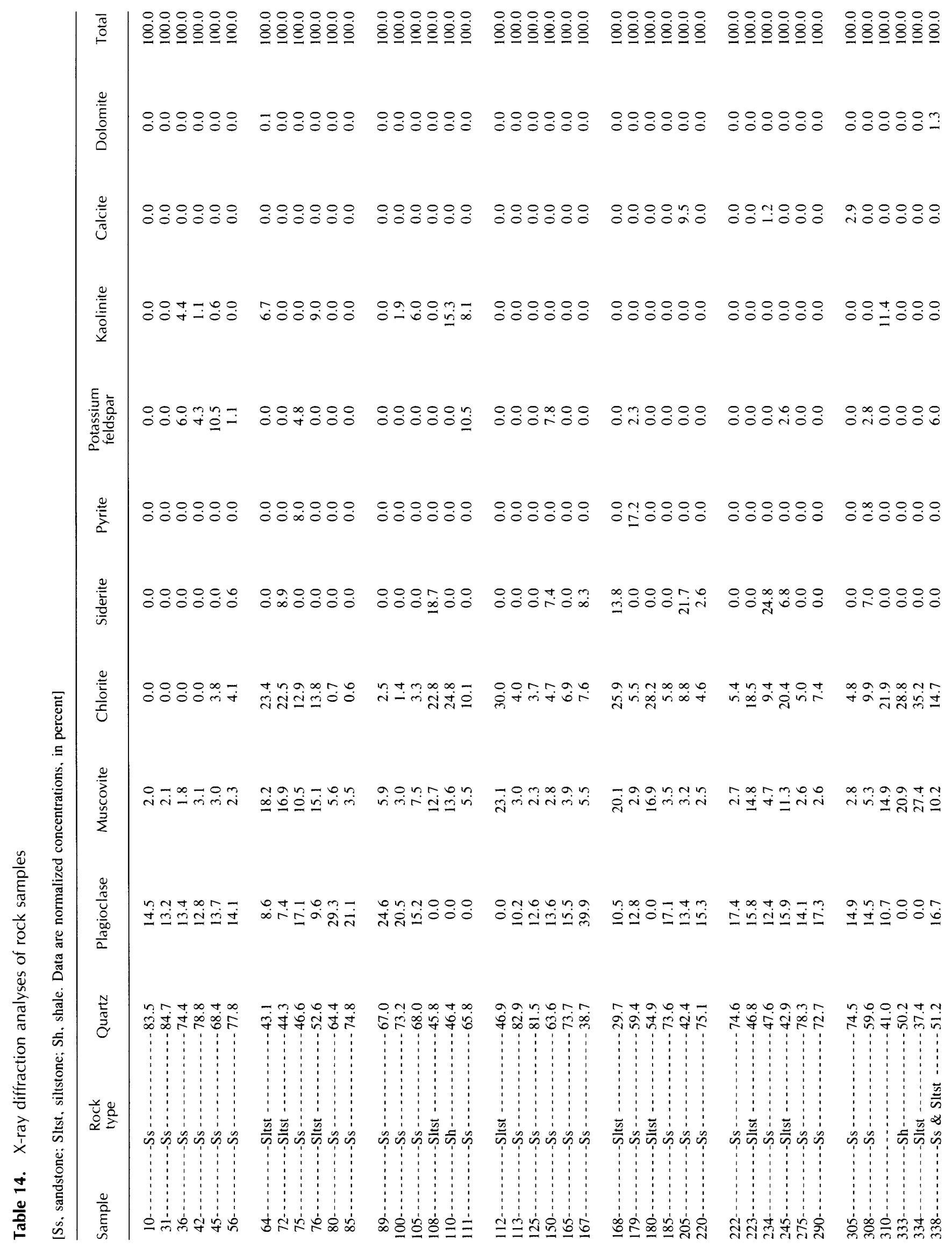

24 Relation Between Ground-Water Quality and Mineralogy, Norton Formation, Va. 


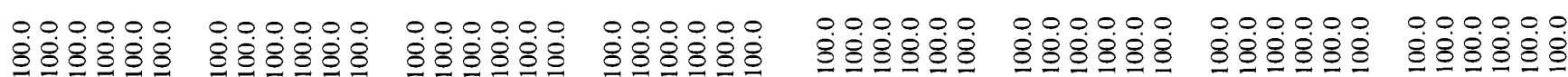
영영여

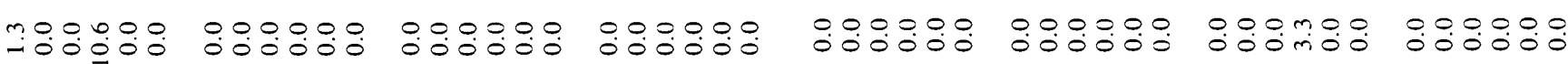

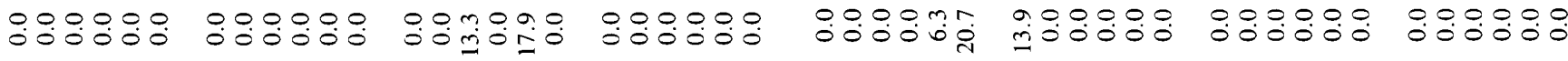

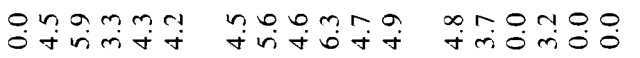

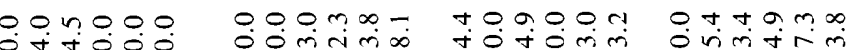
$\dot{0} \dot{0}+\dot{4} \dot{0} \dot{0} 0 \dot{0}$

n웅ㅇㅇㅇ

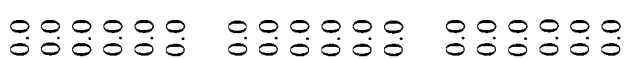

000000

웅유우웅

웅웅우웅

웅ㅇㅇㅇㅇㅇ

웅유융영

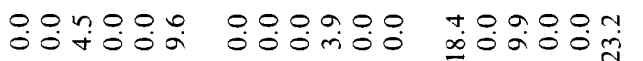

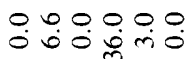

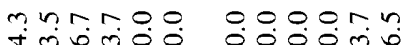

$00000=$

tom mo.

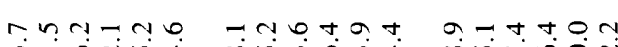

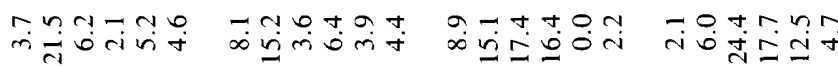

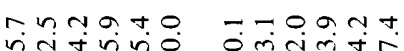

onnisiog

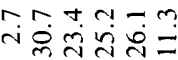

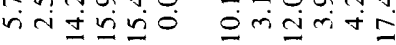

onnamt

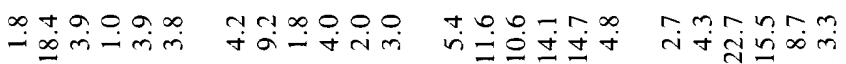

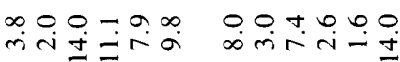

min

$00 \infty$ ำ

mथ-ततm

ง

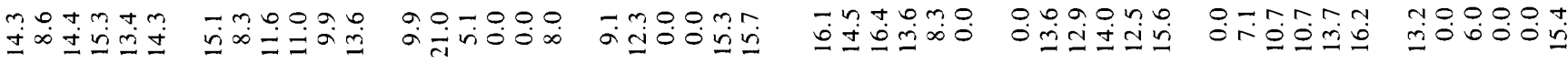

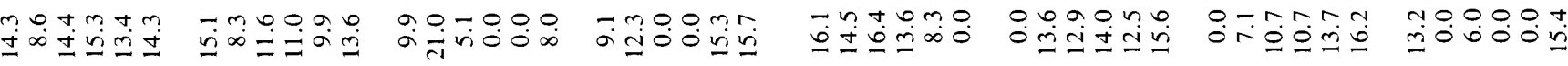

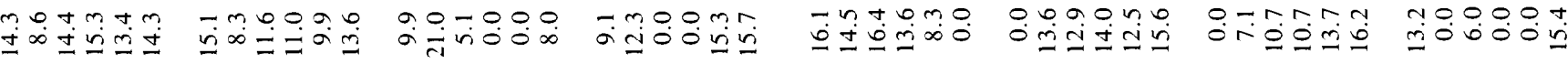

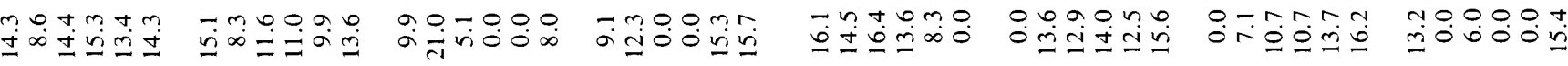

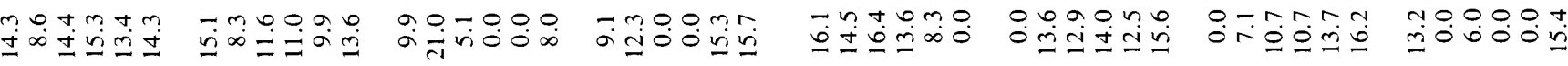

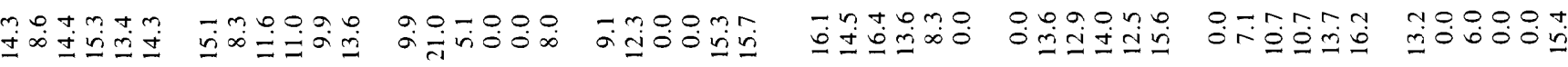

a) a.jun o.

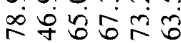

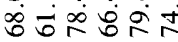
约守守它它

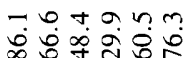

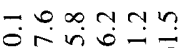

r.tanom

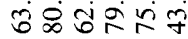

0 on

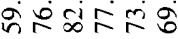

r.r. no no

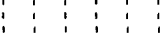

\section{芯蒂}

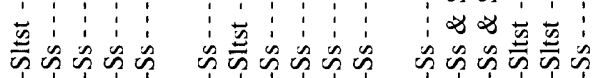

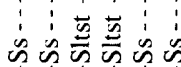

1:

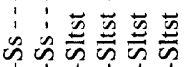

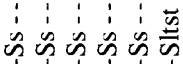

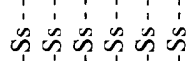

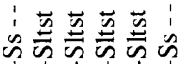

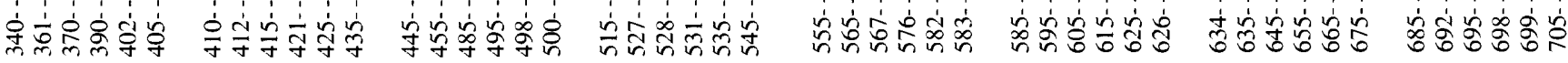




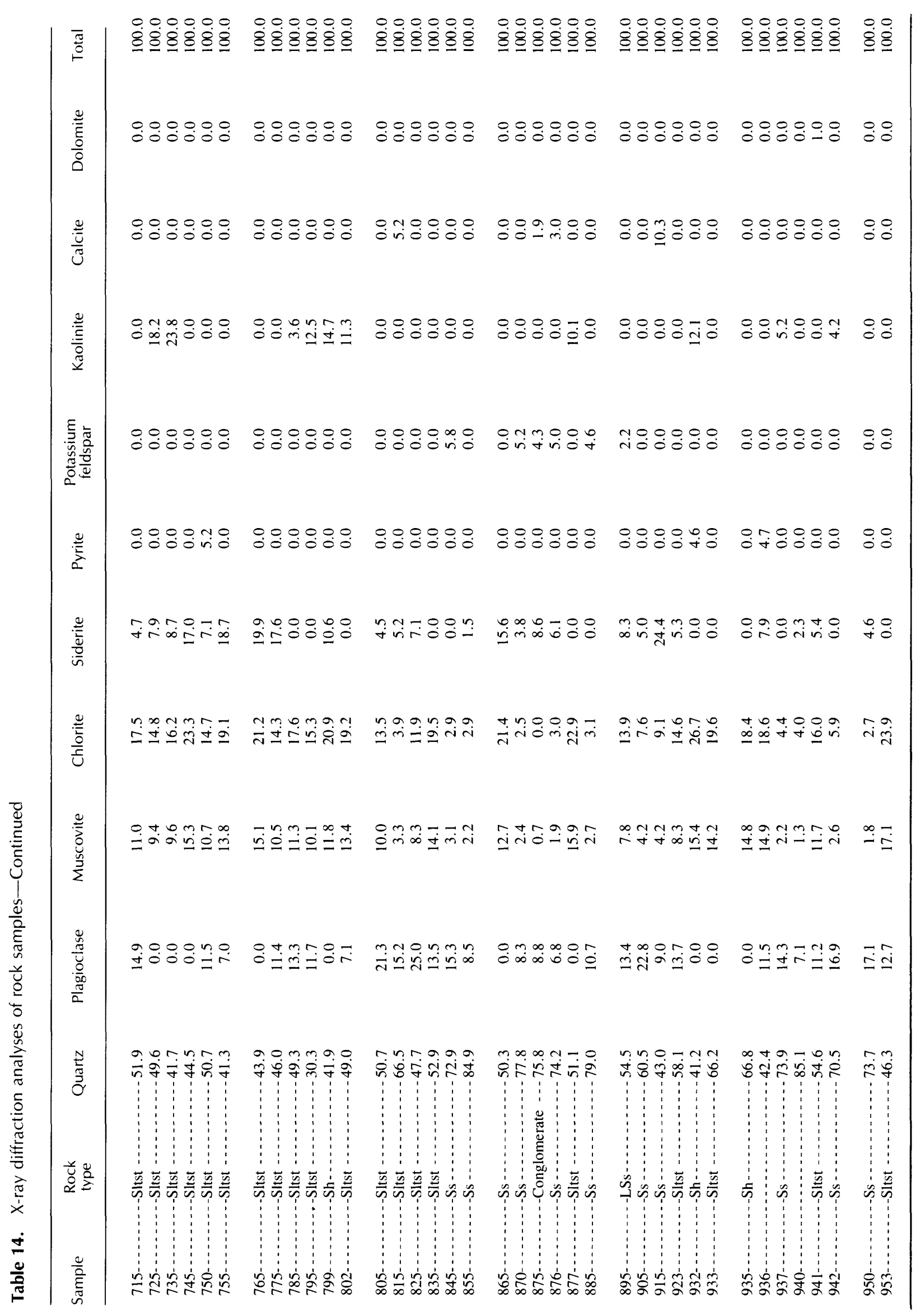


Table 15. Sulfur analyses of rock samples

[Percent of sample, by weight; depth in feet]

\begin{tabular}{|c|c|c|c|c|c|c|c|}
\hline $\begin{array}{l}\text { Depth of } \\
\text { sample }\end{array}$ & $\begin{array}{l}\text { Total } \\
\text { sulfur }\end{array}$ & $\begin{array}{l}\text { Depth of } \\
\text { sample }\end{array}$ & $\begin{array}{l}\text { Total } \\
\text { sulfur }\end{array}$ & $\begin{array}{l}\text { Depth of } \\
\text { sample }\end{array}$ & $\begin{array}{l}\text { Total } \\
\text { sulfur }\end{array}$ & $\begin{array}{l}\text { Depth of } \\
\text { sample }\end{array}$ & $\begin{array}{l}\text { Total } \\
\text { sulfur }\end{array}$ \\
\hline 010 & $<0.01$ & 290 & 0.08 & 576 & 1.73 & 825 & 0.03 \\
\hline 031 & $<0.01$ & 305 & 0.02 & 582 & 1.50 & 835 & 0.05 \\
\hline 036 & 0.02 & 308 & 0.12 & 583 & 0.02 & 845 & 0.01 \\
\hline 042 & $<0.01$ & 310 & 0.13 & 585 & 0.01 & 855 & 0.01 \\
\hline 045 & 0.07 & 333 & 0.07 & 595 & 0.02 & 865 & 0.14 \\
\hline 056 & 0.01 & 334 & 0.01 & 605 & 0.05 & 870 & 0.06 \\
\hline 064 & 0.36 & 338 & 0.05 & 615 & 0.02 & 875 & 0.03 \\
\hline 072 & 0.21 & 340 & 0.02 & 625 & 0.01 & 876 & 0.02 \\
\hline 075 & 1.71 & 361 & 0.01 & 626 & 0.05 & 877 & 0.01 \\
\hline 076 & 0.09 & 370 & 0.01 & 634 & 0.05 & 885 & 0.01 \\
\hline 080 & $<0.01$ & 390 & 0.01 & 635 & 0.01 & 895 & 0.34 \\
\hline 085 & $<0.01$ & 402 & 0.03 & 645 & 0.01 & 905 & 0.09 \\
\hline 089 & $<0.01$ & 405 & $<0.01$ & 655 & 0.01 & 925 & 0.05 \\
\hline 100 & $<0.01$ & 410 & 0.12 & 665 & 0.01 & 932 & 4.96 \\
\hline 105 & $<0.01$ & 412 & 0.05 & 675 & 0.01 & 933 & 0.06 \\
\hline 108 & 0.02 & 415 & 0.02 & 685 & $<0.01$ & 935 & 0.06 \\
\hline 110 & 0.05 & 421 & 0.02 & 692 & 0.05 & 936 & 0.68 \\
\hline 111 & 0.17 & 425 & 0.01 & 695 & 0.04 & 937 & 0.02 \\
\hline 112 & 0.02 & 435 & 0.01 & 698 & 0.16 & 940 & 0.04 \\
\hline 113 & 0.03 & 445 & 0.14 & 699 & 0.01 & 941 & 0.05 \\
\hline 125 & 0.04 & 455 & 0.17 & 705 & 0.02 & 942 & 0.01 \\
\hline 150 & 0.14 & 485 & 0.07 & 715 & 0.03 & 950 & 0.01 \\
\hline 165 & 0.03 & 495 & 0.01 & 725 & 0.20 & 953 & 0.04 \\
\hline 167 & 0.19 & 498 & 0.02 & 735 & 0.18 & 999 & 0.01 \\
\hline 168 & 0.11 & 500 & 0.01 & 745 & 0.16 & $\begin{array}{l}\text { (Clay } \\
\text { laver }\end{array}$ & \\
\hline 179 & 4.14 & 515 & $<0.01$ & 750 & 0.84 & at 50 & \\
\hline 180 & 0.12 & 516 & 0.03 & 755 & 0.28 & $\mathrm{ft})$ & \\
\hline 185 & 0.03 & 527 & 0.18 & 765 & 0.13 & & \\
\hline 205 & 0.06 & 528 & 0.10 & 775 & 0.05 & & \\
\hline 220 & 0.18 & 531 & 0.02 & 785 & 0.04 & & \\
\hline 222 & 0.03 & 535 & 0.16 & 795 & 0.05 & & \\
\hline 223 & 0.10 & 545 & 0.02 & 799 & 0.09 & & \\
\hline 234 & 0.18 & 555 & 0.01 & 802 & 0.01 & & \\
\hline 245 & 0.14 & 565 & 0.08 & 805 & 0.01 & & \\
\hline 275 & 0.01 & 567 & 0.06 & 815 & 0.01 & & \\
\hline
\end{tabular}


Table 16. Chemical analyses of groun

\begin{tabular}{|c|c|c|c|c|c|c|c|c|c|}
\hline Local identifier & Latitude & Longitude & $\begin{array}{l}\text { Alt. of well } \\
\text { bottom } \\
\text { datium (ft. } \\
\text { NGVD) }\end{array}$ & $\begin{array}{l}\text { Depth } \\
\text { of well, } \\
\text { total } \\
\text { (feet) }\end{array}$ & $\begin{array}{l}\text { Date of } \\
\text { sample } \\
\text { (1981) }\end{array}$ & $\begin{array}{c}\text { Specific } \\
\text { conductance } \\
\text { (micromhos) }\end{array}$ & $\begin{array}{c}\mathrm{pH} \\
\text { field } \\
\text { (units) }\end{array}$ & $\begin{array}{c}\text { Hardness } \\
(\mathrm{mg} / \mathrm{L} \text { as } \\
\left.\mathrm{CaCO}_{3}\right)\end{array}$ & $\begin{array}{c}\text { Hardness, } \\
\text { noncarbonat } \\
(\mathrm{mg} / \mathrm{L} \text { as } \\
\left.\mathrm{CaCO}_{3}\right)\end{array}$ \\
\hline 14ES12 P. McGloth Spg. . . . . . . & $.37^{\circ} 07^{\prime} 04^{\prime \prime}$ & $82^{\circ} 03^{\prime} 34^{\prime \prime}$ & 2,580 & --- & $6-11$ & 39 & 5.4 & 6 & 0 \\
\hline 14ES 3 Martin Bath Spg. . . . . . & . $06^{\prime} 26^{\prime \prime}$ & $02^{\prime} 21^{\prime \prime}$ & 2,510 & --- & $1-16$ & 24 & 6.3 & 6 & 0 \\
\hline 14ES11 R. Rutherford Spg. . . . . . . & $06^{\prime} 10^{\prime \prime}$ & $03^{\prime} 29^{\prime \prime}$ & 2.485 & --- & $6-11$ & 28 & 5.8 & 5 & 2 \\
\hline 14ES 6 A.L. Hess Spg. . . . . . . . . & $06^{\prime} 37^{\prime \prime}$ & $03^{\prime} 24^{\prime \prime}$ & 2.440 & --- & $2-18$ & 30 & 5.1 & 5 & 0 \\
\hline 14E 23 Perry Glothlin ........... & $07^{\prime} 01^{\prime \prime}$ & $03^{\prime} 32^{\prime \prime}$ & 2.210 & 285 & $6-11$ & 320 & 6.6 & 140 & 0 \\
\hline 143S 9 Ida Saunders Spg. . . . . . . . & $06^{\prime} 41^{\prime \prime}$ & $02^{\prime} 38^{\prime \prime}$ & 2.180 & $-\cdots$ & $2-20$ & 35 & 5.5 & 9 & 6 \\
\hline 14E 14 Arthur Lee Hess . . . . . . . . & $06^{\prime} 22^{\prime \prime}$ & $03^{\prime} 24^{\prime \prime}$ & 2.115 & 9.5 & $1-21$ & 283 & 6.1 & 95 & 45 \\
\hline 14ES 8 Pete Harris Spg. . . . . . . . & $06^{\prime} 39^{\prime \prime}$ & $02^{\prime} 56^{\prime \prime}$ & 2.105 & --- & $2-20$ & 48 & 5.4 & 13 & 8 \\
\hline 14ES 2 Hess Cow Spg. . . . . . . . . & $05^{\prime} 26^{\prime \prime}$ & $02^{\prime} 35^{\prime \prime}$ & 2.065 & --- & $1-16$ & 234 & 6.4 & 110 & 0 \\
\hline 14ES 5 Stewart Harris Spg. ........ & $05^{\prime} 54^{\prime \prime}$ & $02^{\prime} 20^{\prime \prime}$ & 2,023 & -- & $2-17$ & 54 & 5.3 & 13 & 11 \\
\hline 14E 12 Martha B. Thomas ........ & $05^{\prime} 52^{\prime \prime}$ & $02^{\prime} 54^{\prime \prime}$ & 2,023 & 50 & $1-21$ & 277 & 6.6 & 74 & 0 \\
\hline 14E 13 Chester McGlothin . ...... & $06^{\prime} 09^{\prime \prime}$ & $03^{\prime} 00^{\prime \prime}$ & 2,023 & 20 & $1-21$ & 127 & 6.6 & 41 & 8 \\
\hline 14E 19 Ruben Harris . . . . . . . . . . . & $06^{\prime} 01^{\prime \prime}$ & $02^{\prime} 15^{\prime \prime}$ & 2.017 & 57 & $2-18$ & 177 & 5.8 & 46 & 0 \\
\hline 14E 24 Jerry Bostick . . . . . . . . . & $06^{\prime} 04^{\prime \prime}$ & $02^{\prime} 54^{\prime \prime}$ & 2,017 & 83 & $6-11$ & 270 & 7.2 & 98 & 0 \\
\hline 14E 20 Donald Austin & $07^{\prime} 45^{\prime \prime}$ & $03^{\prime} 11^{\prime \prime}$ & 2.010 & 63 & $2-18$ & 152 & 5.8 & 46 & 0 \\
\hline 14ES 1 Hess Driveway Spg. . . . . . & $05^{\prime} 28^{\prime \prime}$ & $02,37^{\prime \prime}$ & 2,010 & --- & $1-16$ & 102 & 6.7 & 37 & 8 \\
\hline 14E 22 J.M. Bovd $\ldots \ldots \ldots \ldots \ldots$ & $06^{\prime} 17^{\prime \prime}$ & $03^{\prime} 16^{\prime \prime}$ & 1,970 & 90 & $6-11$ & 146 & 6.4 & 53 & 0 \\
\hline 14E 17 Bill Sheppard ............. & $05^{\prime} 42^{\prime \prime}$ & $02^{\prime} 22^{\prime \prime}$ & 1,933 & 67 & $2-18$ & 121 & 5.3 & 46 & 0 \\
\hline 14E 11 Arthur B. Hess . .......... & $05^{\prime} 23^{\prime \prime}$ & $02^{\prime} 57^{\prime \prime}$ & 1,923 & 30 & $1-20$ & 161 & 6.6 & 63 & 15 \\
\hline 14E 16 Paul Harris...$\ldots \ldots \ldots$ & $05^{\prime} 28^{\prime \prime}$ & $02^{\prime} 18^{\prime \prime}$ & 1.910 & 80 & $2-17$ & 136 & 5.8 & 51 & 0 \\
\hline 14E 5 lrvine Combs $\ldots \ldots \ldots \ldots$ & $05^{\prime} 14^{\prime \prime}$ & $02^{\prime} 45^{\prime \prime}$ & 1.906 & 19 & $1-19$ & 226 & 6.1 & 89 & 38 \\
\hline 14E 10 Howard Hess $\ldots \ldots \ldots \ldots$. & $05^{\prime} 28^{\prime \prime}$ & $02^{\prime} 38^{\prime \prime}$ & 1.887 & 123 & $1-20$ & 197 & 6.3 & 60 & 0 \\
\hline 14E 15 Michael Harris......... & $05^{\prime} 08^{\prime \prime}$ & $02^{\prime} 08^{\prime \prime}$ & 1,880 & 60 & $2-17$ & 197 & 6.8 & 51 & 0 \\
\hline 14ES 7 Mike Harris $\ldots \ldots \ldots \ldots$ & $05^{\prime} 07^{\prime \prime}$ & $02^{\prime} 06^{\prime \prime}$ & 1,880 & -- & $2-18$ & 207 & 5.9 & 100 & 86 \\
\hline 14E 18 Steward Harris..$\ldots \ldots \ldots$ & $05^{\prime} 37^{\prime \prime}$ & $02^{\prime} 19^{\prime \prime}$ & 1,845 & 180 & $2-18$ & 162 & 5.7 & 50 & 22 \\
\hline $14 \mathrm{E} 99$ Curtis Austin............... & $05^{\prime} 00^{\prime \prime}$ & $02^{\prime} 04^{\prime \prime}$ & 1.823 & 52 & $1-20$ & 178 & 6.5 & 69 & 0 \\
\hline 14ES 4 Lethridge Spg. ............. & $04^{\prime} 38^{\prime \prime}$ & $02^{\prime} 19^{\prime \prime}$ & 1,800 & $\cdots$ & $2-20$ & 312 & 6.4 & 67 & 0 \\
\hline 14E 8 Eugene Austin ........... & $04^{\prime} 45^{\prime \prime}$ & $02^{\prime} 27^{\prime \prime}$ & 1,740 & 90 & $1-20$ & 256 & 7.6 & 7 & 0 \\
\hline 14E 6 Robert E. Austin .......... & $04^{\prime} 42^{\prime \prime}$ & $02^{\prime} 22$ & 1,707 & 98 & $1-19$ & 221 & 6.9 & 68 & 0 \\
\hline 14E 7 Vilinie Hess $\ldots \ldots \ldots \ldots$ & $04^{\prime} 36^{\prime \prime}$ & $02^{\prime} 22^{\prime \prime}$ & 1.703 & 90 & $1-19$ & 268 & 6.7 & 62 & 0 \\
\hline 14ES10 Bennie Harris Spg. . . . . . . & $06^{\prime} 22^{\prime \prime}$ & $03^{\prime} 15^{\prime \prime}$ & 2,135 & $\cdots$ & $6-11$ & 44 & 6.4 & 13 & 5 \\
\hline 14E 21 Don Harris ............... & $06^{\prime} 32^{\prime \prime}$ & $03^{\prime} 01^{\prime \prime}$ & 2,005 & 53 & $2-20$ & 125 & 6.7 & 46 & 0 \\
\hline
\end{tabular}


'ater sampled in the study area

\begin{tabular}{|c|c|c|c|c|c|c|c|c|c|c|}
\hline $\begin{array}{l}\text { Calcium, } \\
\text {-issolved } \\
\text { (mg/L as } \\
\text { Ca) }\end{array}$ & $\begin{array}{c}\text { Magnesium, } \\
\text { dissolved } \\
\text { (mg/L as } \\
\mathrm{Mg})\end{array}$ & $\begin{array}{c}\text { Sodium, } \\
\text { dissolved } \\
\text { (mg/L as } \\
\mathrm{Ne})\end{array}$ & $\begin{array}{c}\text { Potassium, } \\
\text { dissolved } \\
\text { (mg/L as } \\
\text { K) }\end{array}$ & $\begin{array}{l}\text { Iron, } \\
\text { dissolved } \\
(\mu g / L \text { as } \\
\text { Fe) }\end{array}$ & $\begin{array}{c}\text { Alkalinity } \\
(\mathrm{mg} / \mathrm{L} \text { as } \\
\left.\mathrm{CaCO}_{3}\right)\end{array}$ & $\begin{array}{c}\text { Sulfate, } \\
\text { dissolved } \\
(\mathrm{mg} / \mathrm{L} \text { as } \\
\left.\mathrm{SO}_{4}\right)\end{array}$ & $\begin{array}{c}\text { Chloride, } \\
\text { dissolved } \\
\text { (mg/L as } \\
\text { C1) }\end{array}$ & $\begin{array}{c}\text { Silica, } \\
\text { dissolved } \\
(\mathrm{mg} / \mathrm{L} \text { as } \\
\left.\mathrm{SiO}_{2}\right)\end{array}$ & $\begin{array}{l}\text { Solids, } \\
\text { residue } \\
\text { at } 180^{\circ} \mathrm{C}, \\
\text { dissolved } \\
\text { (mg/L) }\end{array}$ & $\begin{array}{c}\text { Man- } \\
\text { ganese, } \\
\text { dissolved } \\
\text { ( } \mu \mathrm{g} / \mathrm{L} \text { as } \\
\mathrm{Mn})\end{array}$ \\
\hline 1.0 & .9 & 2.8 & 1.3 & 100 & 17 & 2.7 & 1.8 & 13 & 44 & 70 \\
\hline 1.0 & .8 & 1.9 & .7 & 60 & 10 & 4.0 & .7 & 16 & 27 & 40 \\
\hline 1.1 & .6 & 1.6 & 1.0 & $<10$ & 3 & 1.0 & 2.0 & 11 & 30 & 1 \\
\hline .7 & .7 & 2.0 & .8 & 10 & 12 & 1.8 & .6 & 14 & 25 & 0 \\
\hline 39. & 9.7 & 8.9 & 1.5 & $<10$ & 140 & 14 & 1.5 & 16 & 186 & 0 \\
\hline 2.1 & 1.0 & 1.3 & .7 & 30 & 3 & 7.3 & .6 & 7.5 & 24 & 10 \\
\hline 27. & 6.7 & 7.3 & 13 & $<10$ & 50 & 33 & 15 & 8.9 & 191 & 9 \\
\hline 2.7 & 1.4 & 1.6 & .9 & 20 & 5 & 5.9 & .7 & 7.8 & 30 & 3 \\
\hline 27. & 9.5 & 7.9 & 1.7 & 760 & 112 & 13 & .9 & 18 & 149 & 40 \\
\hline 2.3 & 1.7 & 2.0 & 1.0 & 30 & 4 & 8.8 & 2.6 & 8.1 & 37 & 0 \\
\hline 20. & 5.4 & 26. & 1.4 & 50 & 138 & 2.5 & .8 & 16 & 151 & 50 \\
\hline 10. & 3.8 & 5.7 & 4.5 & 30 & 33 & 9.6 & 4.3 & 8.1 & 83 & 10 \\
\hline 12. & 3.8 & 6.7 & .9 & 58 & 58 & 2.3 & 1.1 & 16 & 80 & 200 \\
\hline 27. & 7.3 & 18. & 1.3 & 310 & 120 & 11 & 3.0 & 15 & 177 & 60 \\
\hline 13. & 3.3 & 9.1 & .8 & 320 & 58 & 4.2 & .9 & 14 & 85 & 190 \\
\hline 7.5 & 4.4 & 4.0 & 1.2 & 60 & 29 & 14 & 1.0 & 9.8 & 63 & 4 \\
\hline 15. & 3.6 & 8.2 & .9 & 5,900 & 35 & 8.0 & 3.8 & 16 & 102 & 320 \\
\hline 12. & 3.8 & 5.4 & .8 & 70 & 52 & 5.3 & 1.1 & 19 & 78 & 120 \\
\hline 15. & 6.2 & 5.5 & 2.5 & 40 & 48 & 14 & 11 & 9.9 & 100 & 2 \\
\hline 13. & 4.5 & 10. & 1.1 & 60 & 70 & 1.4 & 1.2 & 18 & 89 & 80 \\
\hline 21. & 8.9 & 4.6 & 2.3 & 20 & 51 & 34 & 14 & 5.3 & 122 & 20 \\
\hline 17. & 4.0 & 15. & 1.4 & 410 & 101 & .9 & 2.8 & 16 & 114 & 100 \\
\hline 14. & 3.7 & 18. & 1.2 & 1,700 & 86 & 2.8 & 2.5 & 16 & 107 & 120 \\
\hline 21. & 12 & 3.1 & 1.8 & 10 & 16 & 84 & 1.3 & 5.9 & 154 & 3 \\
\hline 12. & 4.7 & 7.1 & .8 & 11,000 & 28 & 35 & 2.2 & 16 & 109 & 660 \\
\hline 18. & 5.6 & 7.2 & 1.4 & 1,600 & 87 & 4.3 & 1.8 & 19 & 112 & 290 \\
\hline 17. & 5.9 & 39. & 1.8 & 880 & 128 & 22 & 7.8 & 14 & 190 & 160 \\
\hline 2.0 & .5 & 53. & 1.5 & 150 & 140 & 7.6 & 1.8 & 10 & 170 & 4 \\
\hline 19. & 4.7 & 16. & 2.1 & 1,000 & 91 & 17 & 2.3 & 16 & 133 & 70 \\
\hline 18. & 4.1 & 31. & 1.7 & 1,600 & 133 & 4.2 & 7.8 & 15 & 164 & 130 \\
\hline 2.7 & 1.5 & 2.1 & 1.3 & 30 & 8 & 8.2 & .9 & 12 & 40 & 2 \\
\hline 13. & 3.2 & 6.5 & .7 & 4,700 & 50 & 8.4 & 2.3 & 18 & 83 & 230 \\
\hline
\end{tabular}




\section{METRIC CONVERSION FACTORS}

For readers who prefer to use International System of Units (SI), conversion factors for terms used in this report are listed below:

\begin{tabular}{rrl} 
Multiply inch-pound unit & By & To obtain Sl unit \\
\hline $\mathrm{ft}$ (foot) & 0.3048 & $\mathrm{~m}$ (meters) \\
$\mathrm{mi}(\mathrm{mile})$ & 1.609 & $\mathrm{~km}$ (kilometer) \\
$\mathrm{mi}^{2}$ (square mile) & 2.590 & $\mathrm{~km}^{2}$ (square kilometer) \\
in (inch) & 0.2540 & $\mathrm{~mm}$ (millimeter) \\
ton (short) & 0.9072 & metric ton \\
temperature $\left({ }^{\circ} \mathrm{F}\right)-32$ & $5 / 9$ & temperature $\left({ }^{\circ} \mathrm{C}\right)$ \\
atm (atmosphere) & 1.01325 & bar \\
\hline
\end{tabular}

30 Relation Between Ground-Water Quality and Mineralogy, Norton Formation, Va. 